\title{
Global Nepticulidae, Opostegidae, and Tischeriidae (Lepidoptera): temporal dynamics of species descriptions and their authors
}

\author{
VIKTORIJA DOBRYNINA ${ }^{1 *}$, JONAS R. STONIS ${ }^{1,6}$, ARŪNAS DIŠKUS ${ }^{2,7}$, \\ M. ALMA SOLIS ${ }^{3,8}$, SVETLANA V. BARYSHNIKOVA $^{4,9}$ \& YOUNG-MIN SHIN Y $^{5,10}$ \\ ${ }^{1}$ Institute of Ecology, Nature Research Centre, Akademijos St. 2, LT-08412, Vilnius, Lithuania. \\ ${ }^{2}$ Vytautas Magnus University, K. Donelaičio g. 58, 44248 Kaunas, Lithuania \\ ${ }^{3}$ Systematic Entomology Laboratory, ARS, USDA, National Museum of Natural History, Smithsonian Institution, Washington, D.C., \\ 20013-7012, USA. \\ ${ }^{4}$ Zoological Institute, Russian Academy of Sciences, Universitetskaya nab. 1, St. Petersburg, Russia. \\ ${ }^{5}$ Division of Forest Biodiversity, Korea National Arboretum, Pocheon, Republic of Korea \\ 6 ఏ"stonis.biotaxonomy@gmail.com; — https://orcid.org/0000-0002-8411-3162 \\ 7 ”diskus.biotaxonomy@gmail.com; ○https://orcid.org/0000-0003-0106-5546 \\ 8 |"|alma.solis@usda.gov; @ittps://orcid.org/0000-0001-6379-1004 \\ 9 |=" parornix@zin.ru; 으ttps://orcid.org/0000-0002-2549-4911 \\ ${ }_{10}$ ”"ymshin89@korea.kr; @ https://orcid.org/0000-0002-0589-8548 \\ *Corresponding author. =" viktorija.dobrynina@gmail.com; ; https://orcid.org/0000-0003-3655-4649
}

\begin{abstract}
This study identifies the number of named and described species of three monotrysian, plant-mining lepidopteran families worldwide: Nepticulidae and Opostegidae (Nepticuloidea), and Tischeriidae (Tischerioidea). At the end of 2021, we estimated that a total of 1000 Nepticulidae species, 197 Opostegidae species, and 170 Tischeriidae species have been described since the taxonomic practice of describing species began in the 18th century. We examine and discuss the history of descriptions and authorship of species worldwide for each of the three families. We found that the total (accumulative) number of species described increased with each time period delineated. About five new species were described per year on average, or about 22 new species were described per year in the 21 st century. We recognize researchers with the most number of described species in these three taxa.
\end{abstract}

Key words: biodiversity inventorying, global fauna, leaf miners, pygmy moths, trumpet moths, white eye-cap moths

\section{Introduction}

Inventorying biodiversity. Hundreds of new species are discovered every year (Davis 2020), but many Earth's species still await description. The task to inventory and monitor global biodiversity is huge (Zhang 2008, 2011; Cutko 2009; La Salle et al. 2009; Pereira et al. 2010; Wheeler et al. 2012a, 2012b), and the speed is far from sufficient (Schmeller et al. 2017). Closing this knowledge gap, also known as the Linnean shortfall (Brito 2010; Hortal et al. 2015) or Wallacean shortfall (Hortal et al. 2015), will require a strong, renewed effort in exploration and taxonomy, as well as the continuing effort to catalogue existing biodiversity data in publicly available databases (Mora $\mathrm{et} \mathrm{al}$. 2011). The availability and quality of such information is essential to understand how global biota function (Pereira et al. 2010), particularly in the face of the current biological annihilation and sixth major extinction event (Ceballos et al. 2017). The description of new species and assembling data about their biology, and trophic or other relationships, are fundamental tasks to the knowledge about endangered biodiversity on our planet (Dubois 2011; Crisci et al. 2020). This task is within the field of biological systematics or taxonomy and has the ultimate goal of documenting and realizing the extent (and significance) of biological diversity (Vane-Wright 1992, 1996). We need a clearer understanding of the total number of species (Larsen 2017), both on terrestrial and aquatic habitats, to reveal the structure and function of ecosystems (May 2011).

Moreover, the inventory of species diversity is often limited to the best-known groups of organisms such as 
vascular plants and larger vertebrates, and too little attention is paid to the remaining $80-90 \%$ of biodiversity components (Puplesis 2002; Hawksworth 2011), such as the world's smallest moths (Lepidoptera). Data about these tiny lepidopterans, along with other organisms, are tools for prompt action on measures to preserve biodiversity and provide support for hypotheses about the early genesis of the Earth's biota (Stonis et al. 2020b). On the other hand, data about larvae of the leaf-mining Lepidoptera can also be useful during the Anthropocene because they are pests or potential pests of wild and cultivated plants (Kuznetzov \& Puplesis 1994; Stonis et al. 2019c, 2021a).

Although plant-mining (including leaf-mining) Lepidoptera are widespread throughout the world, the Palaearctic fauna alone comprises about 35 lepidopteran families (Puplesis 1992), of which, at least some representatives, are associated with a mining habit in photosynthetic plant tissues. Some leaf miners are called optional, or facultative, miners because their larvae are miners only during the first instars of their development (e.g., almost all species of Bucculatricidae and some species of Incurvariidae, Adelidae, some Gracillariidae, Momphidae, Coleophoridae, Gelechiidae, Cosmopterigidae, Alucitidae, Epermeniidae, Plutellidae, Yponomeutidae, Argyresthiidae, Pterophoridae, Pyralidae, Crambidae, Choreutidae). Another category is the obligatory, or mandatory miners or "true miners" because mining occurs during the entire period of the larva's lifetime (e.g., Eriocraniidae, Heliozelidae, Nepticulidae, Opostegidae, Tischeriidae, Acrolepiidae, most species of Lyonetiidae, some Gracillariidae, Coleophoridae, Cosmopterigidae, some species of Incurvariidae, Momphidae, Epermeniidae, Glyphipterigidae, Douglasiidae, Pterophoridae). Among some leaf-mining families, there are only a few species associated with a mining habit, such as in the Crambidae (Solis et al. 2005), whereas in some families, species that mine make up $100 \%$ of the family. For example, as far as is known, in the Palaearctic, all species of Bucculatricidae are optional miners and all species of Nepticulidae, Tischeriidae, and Acrolepiidae are obligatory miners (Puplesis 1992). Meanwhile in the Palaearctic Gracillariidae, about $1 / 3$ of the species are optional miners and about $2 / 3$ are mandatory (Puplesis 1992).

Although in terms of taxonomy, miners are abundant and diverse, the most "popular" and most intensively investigated families of $100 \%$-miners are Gracillariidae, Bucculatricidae, Nepticulidae, Opostegidae, Tischeriidae. Gracillariidae and Bucculatricidae are briefly discussed below, followed by the focus of this paper, Nepticulidae, Opostegidae, and Tischeriidae.

Bucculatricidae, or ribbed cocoon makers, is a cosmopolitan family (excluding New Zealand) currently comprising about 300 described species globally. Historically, the first described species currently classified as Bucculatricidae is Bucculatrix frangutella (Goeze, 1783). Thus, the history of the family's research spans nearly 240 years. Most of the Bucculatricidae species have been discovered and described by the following authors: E. Meyrick (about 50 species worldwide), A. F. Braun (nearly 70 species from the Nearctic), Lord Walsingham (about 10 species worldwide), G. Deschka (about 10 species predominantly from Europe). Many new species have also been described by authors from Russia, mainly by S. Baryshnikova (formerly Seksjaeva) who described 30 species (Kuznetzov et al. 1988; Seksjaeva 1989, 1992, 1996; Baryshnikova 2001, 2005, 2007, 2013). Recently, interesting research data from Africa, including descriptions of new species, were published by W. Mey (see citations in De Prins \& De Prins 2012-2021), Japan (Kobayashi et al. 2010), China (Liao et al. 2019; Liu \& Wang 2019; Wang et al. 2020), and the Neotropical region (Davis et al. 2002; Vargas \& Moreira 2012).

Gracillariidae, or leaf blotch miner moths, is a cosmopolitan family currently comprising about 2000 described species globally. The greatest contribution to knowledge and inventory of Gracillariidae is provided by the unique database (De Prins \& De Prins 2012-2021) including all available taxonomic information on this family, as well as an exhaustive bibliography. Historically, the first described species currently classified as Gracillariidae is Phyllonorycter rajella (Linnaeus, 1758). Thus, the history of the family research spans over 260 years. Most of the Gracillariidae species have been discovered and described by the following authors: E. Meyrick (about 600 species), T. Kumata (nearly 160), L. Vári (more than 100 species); many others having described more than 50 species each (e.g., Lord Walsingham, A. F. Braun). About 30 new species have also been described by authors from Russia (Gerasimov 1930, 1931, 1933; Kuznetzov 1960, 1975, 1979a, 1979b; Ermolaev 1977, 1981, 1986; Kuznetzov \& Baryshnikova 2000, 2001; Kirichenko et al. 2018, 2019). Recently, some interesting research data, including numerous descriptions of new species, were published from the Afrotropical region by Jurate De Prins (De Prins \& Kawahara 2012), from China by numerous researchers (e.g., Liu \& Yuan 1990; Bai \& Li 2009; Zhang et al. 2012; Bai et al. 2015, 2016; Li et al. 2015; Li \& Zhang 2016; Liu et al. 2021). Many new species were also discovered from the Neotropics (e.g., Davis et al. 2002; Landry 2006; Kawahara et al. 2009; Vargas \& Moreira 2012; Brito et al. 2017; etc.).

In this publication, we inventoried three families of tiny obligatory plant-mining lepidopterans: Nepticulidae, 
Opostegidae, and Tischeriidae. The goal of this research is to apply quantitative criteria for the study of species diversity with three model families of mining Lepidoptera to assess and compare the abundance and current knowledge about these taxa.

We summarize and provide precise data on the documentation history of these families for the first time. In recent decades, the study of these particular lepidopteran families has been intensive and productive as never before. Therefore, a global catalog published in 2016 (van Nieukerken et al. 2016a) which reviews Nepticulidae and Opostegidae, does not include approximately $14 \%$ of recently described species of the global Nepticulidae, primarily from Central and South America (species were listed in the following papers by Stonis et al. 2016c, 2017a, 2017c, 2018b, 2018c, 2018d, 2020c, 2021f; Dobrynina et al. 2021).

What do the studied families represent? Nepticuloidea (Nepticulidae and its sister family Opostegidae) and Tischerioidea (Tischeriidae) are phylogenetically primitive monotrysian lepidopterans possessing only a single, common terminal anogenital opening in females. Although there is no current evidence to support a close relationship between these two superfamilies (Regier et al. 2013, 2015), in the past some researchers treated Nepticuloidea and Tischerioidea as very close phylogenetic clades (Davis 1986), or as taxa of the common infraorder Nepticulomorpha (Kuznetzov \& Stekolnikov 1978, 2001). However, Nepticuloidea and Tischerioidea most likely represent two relatively distant lineages (Nielsen \& Kristensen 1996; Kristensen \& Skalski 1999; Regier et al. 2013, 2015).

Nepticulidae, or pygmy moths (Figs 1-14), of Early Cretaceous origin (Doorenweerd et al. 2016), are distributed worldwide and occur in most terrestrial ecosystems, from tundra and temperate forests to arid boreal or subtropical deserts and various tropical habitats, including the lowland rainforest up to the elevations $4,700 \mathrm{~m}$ in the northern Andean bush and grass páramo and the central Andean puna (Stonis et al. 2016c). Externally, pygmy moths are characterized by an expanded scape of the antenna or eye cap, a distinctive frontal tuft of piliform scales on the vertex of the head, a lamellar (or piliform) collar on the back of the head, and a simple wing pattern comprised of one (or two) fascia(e) or spots, or with uniformly coloured forewings. In the male genitalia, there is a usually well-developed, wide, and strongly chitinized phallus possessing distinctive, often large cornuti. General characterization of this highly specialized, predominantly leaf-mining (occasionally gall-making, e.g., see van Nieukerken et al. 2016b) family was published by several researchers, including Newton \& Wilkinson (1982), Scoble (1983), van Nieukerken (1986a, 1986b), Johansson et al. (1990), Puplesis (1994), Puplesis \& Robinson (2000), Puplesis \& Diškus (2003), Diškus \& Stonis (2012), and van Nieukerken et al. (2016a, 2016b). Nepticulidae consists of 18 globally distributed or endemic genera, some well differentiated and easily recognizable, some scarcely diagnosed, and some with their status still in dispute (van Nieukerken et al. 2016b; Stonis et al. 2017c, 1918c, 2018d, 2019b, $2019 \mathrm{c}$ ). About $80 \%$ of the species of this family are less than $6.0 \mathrm{~mm}$ in wingspan, including the world's smallest Lepidoptera with a minimal recorded forewing length of around 1.2-1.3 mm and wingspan 2.6-2.8 $\mathrm{mm}$ (Stonis et al. 2021f). The predominantly monophagous larvae feed in green tissues of a host plant and produce a leaf mine during all instars of the larval stage. Although adults of these leaf miners are often very small or extremely small, a leaf mine produced by a tiny larva can be relatively large on a leaf and cause damage because the larva consumes much of the photosynthetic tissue. Upon significant population increase or explosion, damage to the host plant may be significant or even severe (Puplesis 1994; Puplesis \& Diškus 2003; Stonis et al. 2021a). Except for a few species, pupation usually takes place outside the leaf mine, often in detritus, where the larvae spin a silk, oval-shaped cocoon.

Opostegidae, or white eye-cap moths (Figs 15-21), are distributed worldwide, with the highest diversity in tropical habitats. They are highly distinctive morphologically: adults are dorsoventrally flattened, usually almost entirely white with very few markings, except for strigulae or short fine transverse lines at the forewing apex (Stonis et al. 2020e). There are a few exceptions where adults of white eye-cap moths are not white (Eyer 1966; Davis 1989; Puplesis \& Robinson 1999; Davis \& Stonis 2007; Stonis et al. 2021g). Most species are between 5.8 and $6.8 \mathrm{~mm}$ in wingspan, although some reach over $10 \mathrm{~mm}$ in wingspan. The smallest known Opostegidae species are about 4.0-4.7 $\mathrm{mm}$ (Stonis et al. 2021f). The largest opostegid is the female of the Chilean Notiopostega atrata Davis with a wingspan of over $17 \mathrm{~mm}$ (Davis 1989). The opostegid antennal scape or eye cap is greatly extended and entirely covers the eye of a resting moth, except for some Neopostega Davis. The frontal tuft is small and usually white, and comprised of short piliform scales; the collar is shield-like, large, and covers the back of the head and overlaps the thorax. In the male genitalia, opostegids have a pedunculate cucullar lobe on the valva, which bears a distinctive pectinifer of blunt spines and is connected to the valva by a pedicellum (Davis \& Stonis 2007). For a detailed morphological characterization of the family, we recommend Davis (1989), Puplesis \& Robinson (1999), and Davis \& Stonis (2007). 

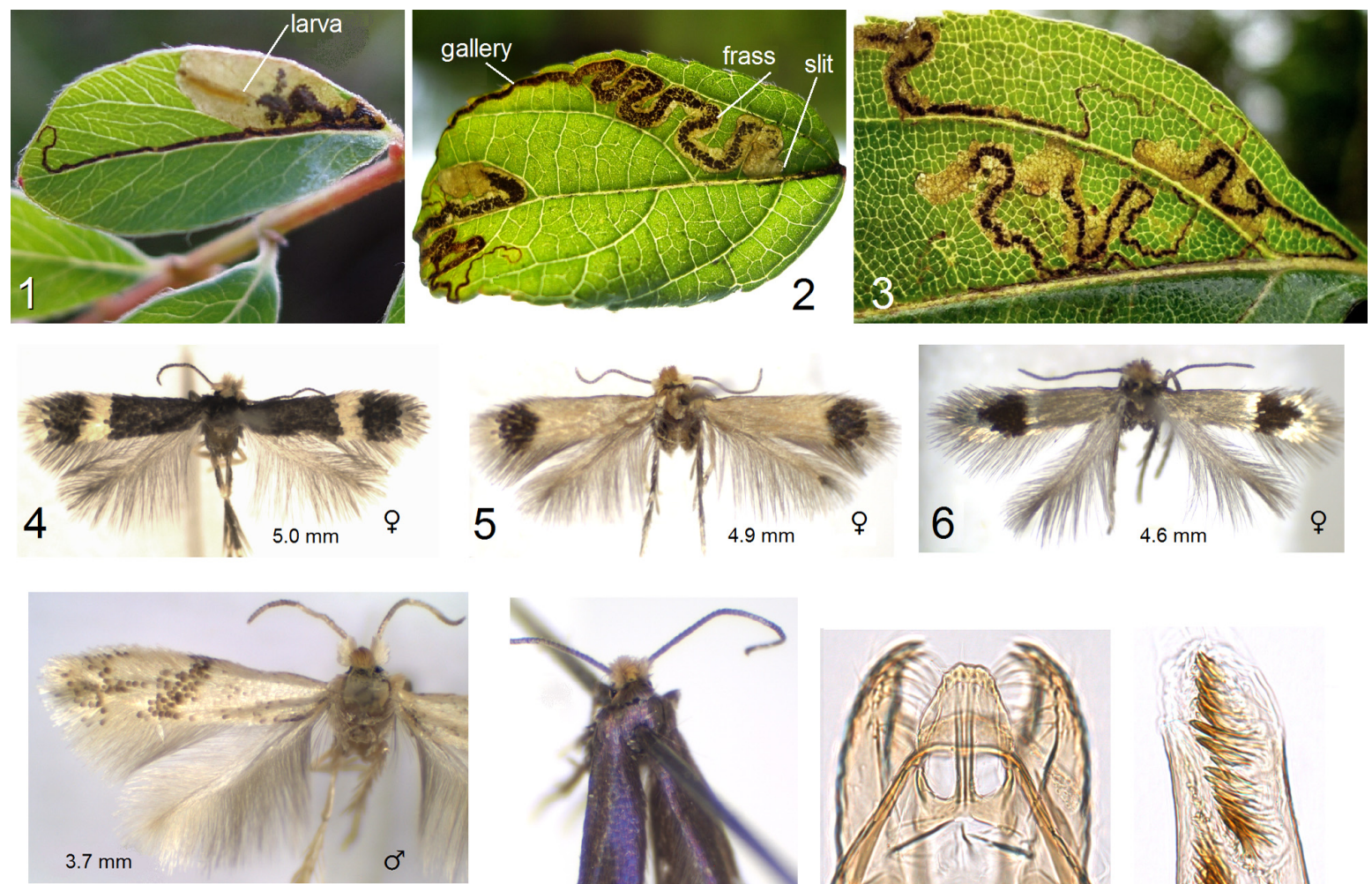

7
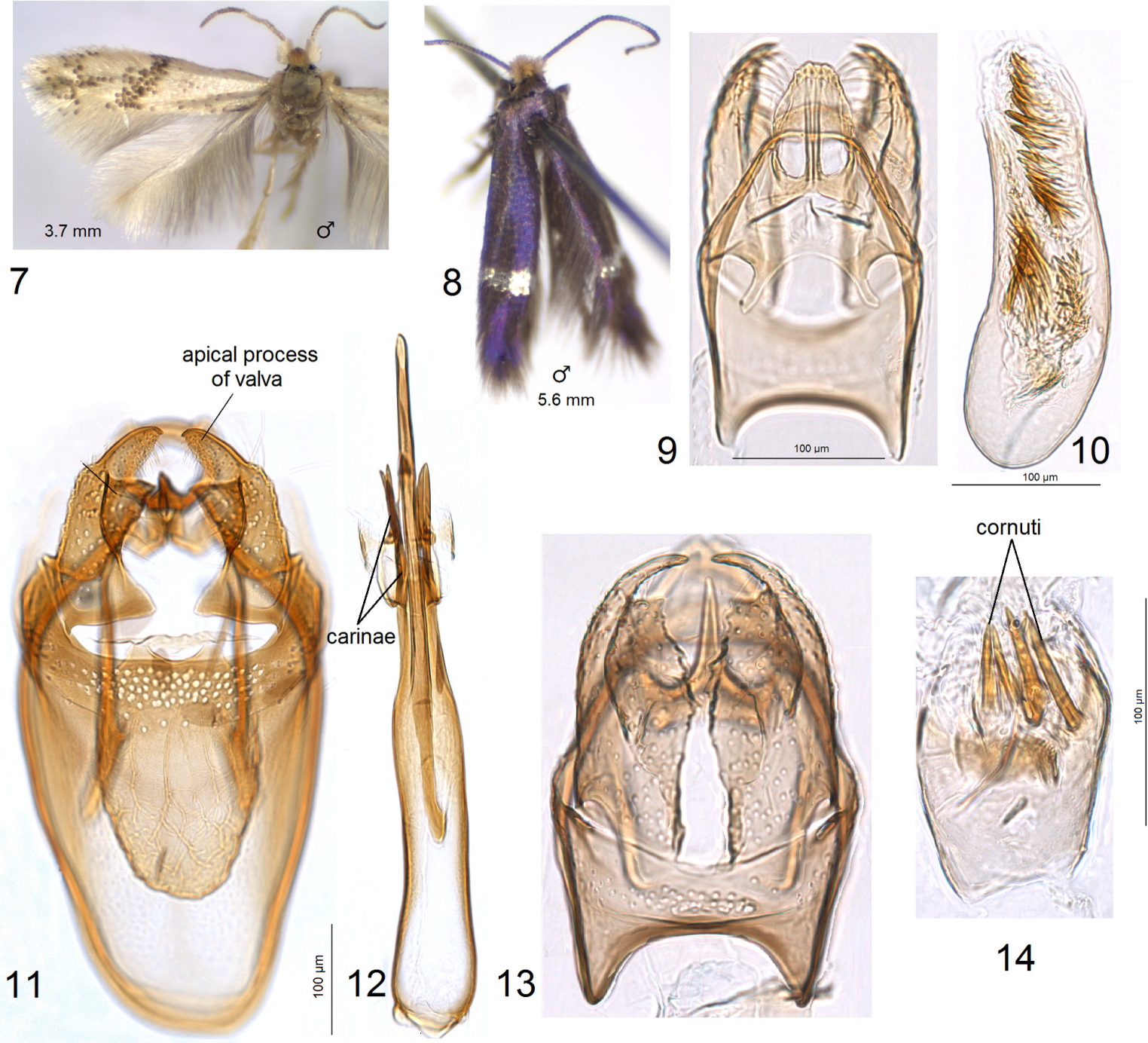

14

FIGURES 1-14. Nepticulidae, pygmy moths. 1, leaf mine of Stigmella decora Diškus \& Stonis on Rhynchotheca, Ecuador; 2 , same, S. apicibrunella Diškus \& Stonis on Acalypha, Ecuador (Stonis et al. 2017b); 3, same, S. baccharicola Diškus \& Stonis on Baccharis, Ecuador (Stonis et al. 2016b); 4, adult of S. podanthae Diškus \& Stonis, Chile (Stonis et al. 2016a); 5, same, S. apicibrunella Diškus \& Stonis, Ecuador; 6, same, S. decora Diškus \& Stonis, Ecuador (Stonis et al. 2017b); 7, same, Acalyptris minimus Diškus \& Stonis, Ecuador (Stonis et al. 2018e); 8, same, Manoneura trinaria Puplesis \& Robinson, Venezuela (Stonis et al. 2018d); 9, 10, male genitalia of S. apicibrunella Diškus \& Stonis, Ecuador (Stonis et al. 2017b); 11, 12, same, Manoneura forcipis Remeikis \& Stonis, Peru (Stonis et al. 2017a); 13, 14, same, S. decora Diškus \& Stonis, Ecuador (Stonis et al. 2017b) 

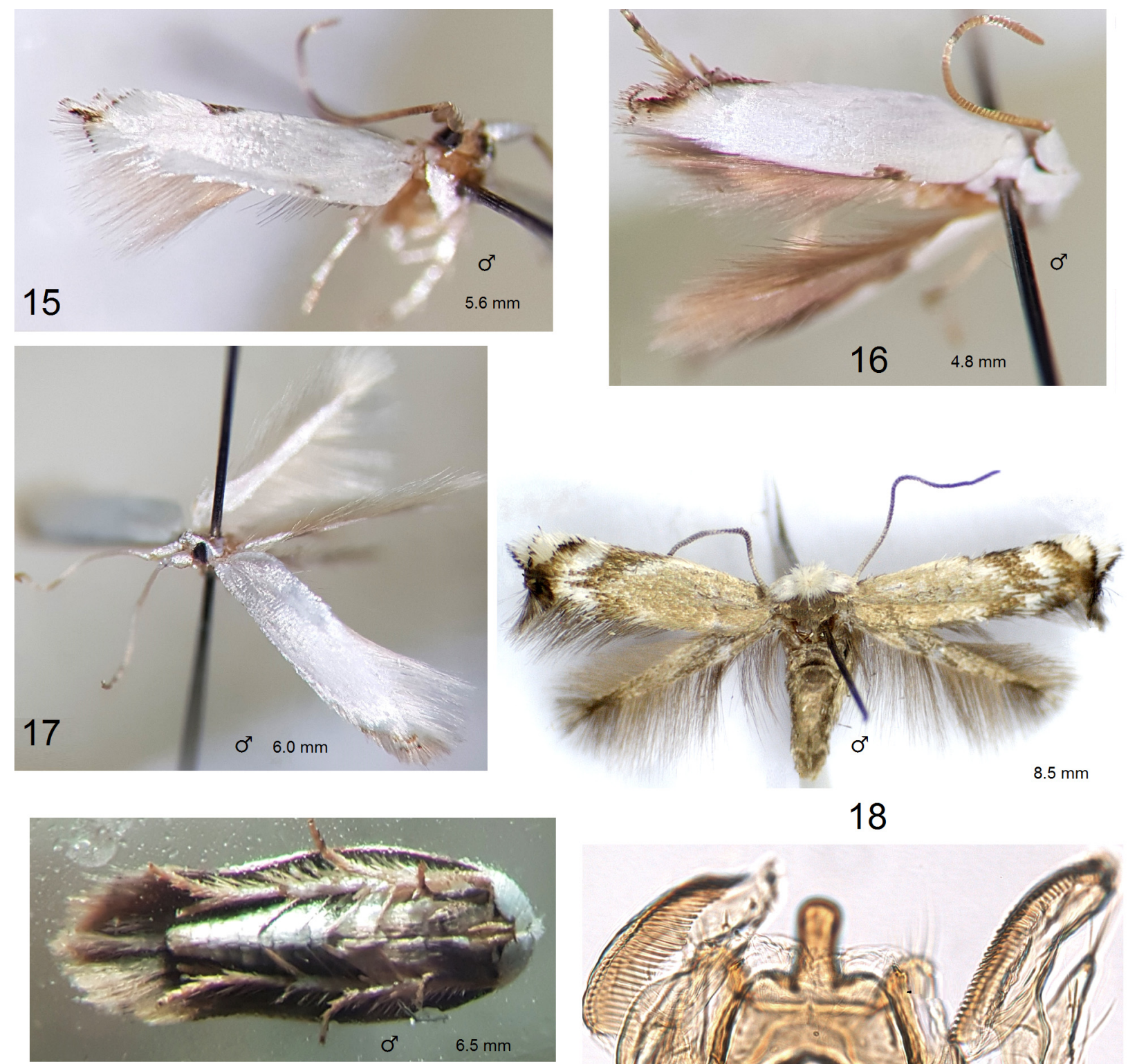

19
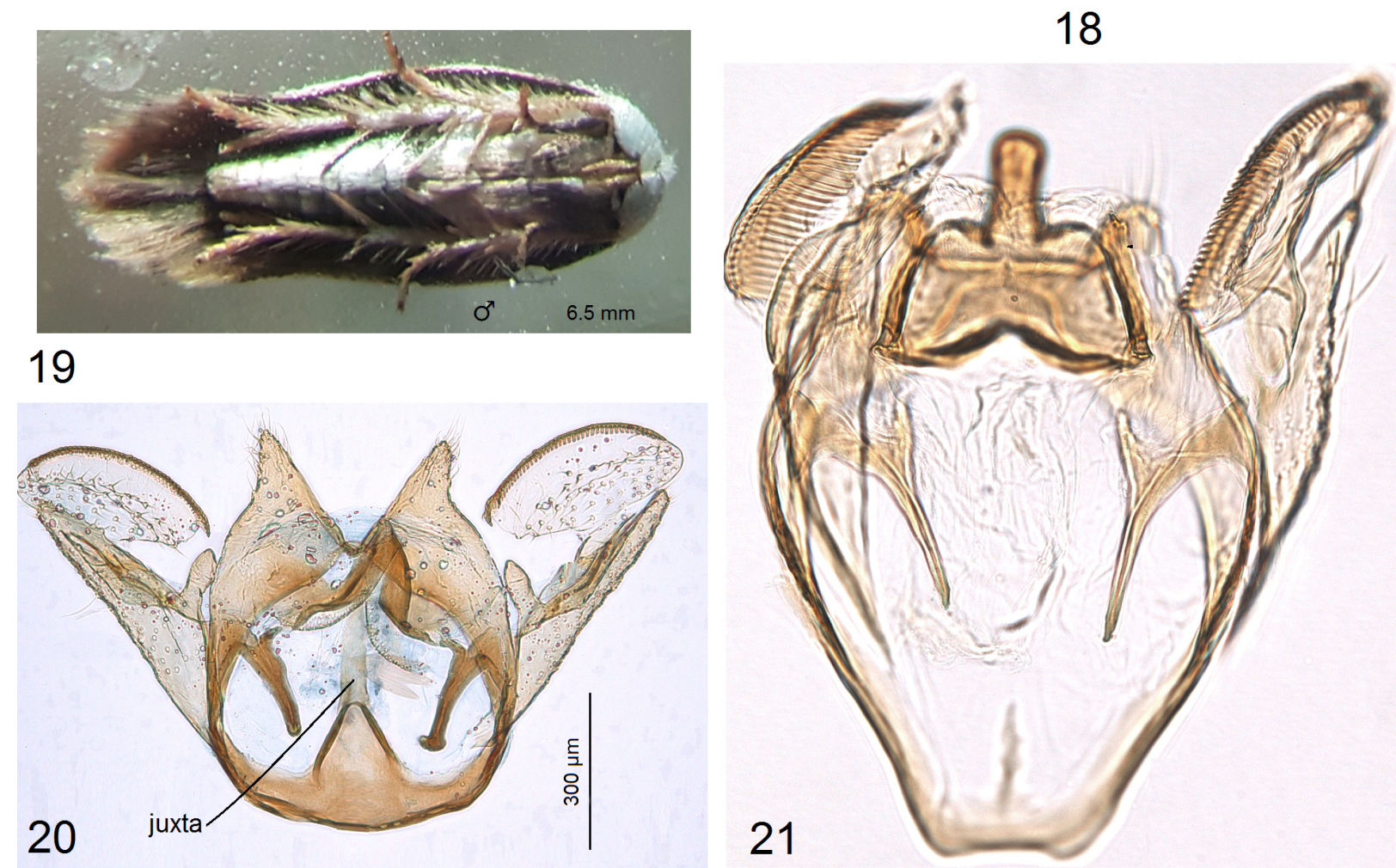

FIGURES 15-21. Opostegidae, white eye-cap moths. 15, adult of Pseudopostega sacculata (Meyrick, 1915), Peru; 16, same, P. spinosa Stonis \& Diškus, Ecuador; 17, same, Neopostega dondavisi Stonis \& Remeikis, Peru (Stonis et al. 2020e); 18, same, Pseudopostega matrona Karsholt \& Remeikis, Turkey (Stonis et al. 2021g); 19, same, P. cucullata Stonis \& Vargas, Colombia (Stonis et al. 2020e); 20, male genitalia of P. matrona Karsholt \& Remeikis, Turkey (Stonis et al. 2021g); 21, same, P. apotoma Davis \& Stonis, 2007, Peru (Stonis et al. 2020e) 

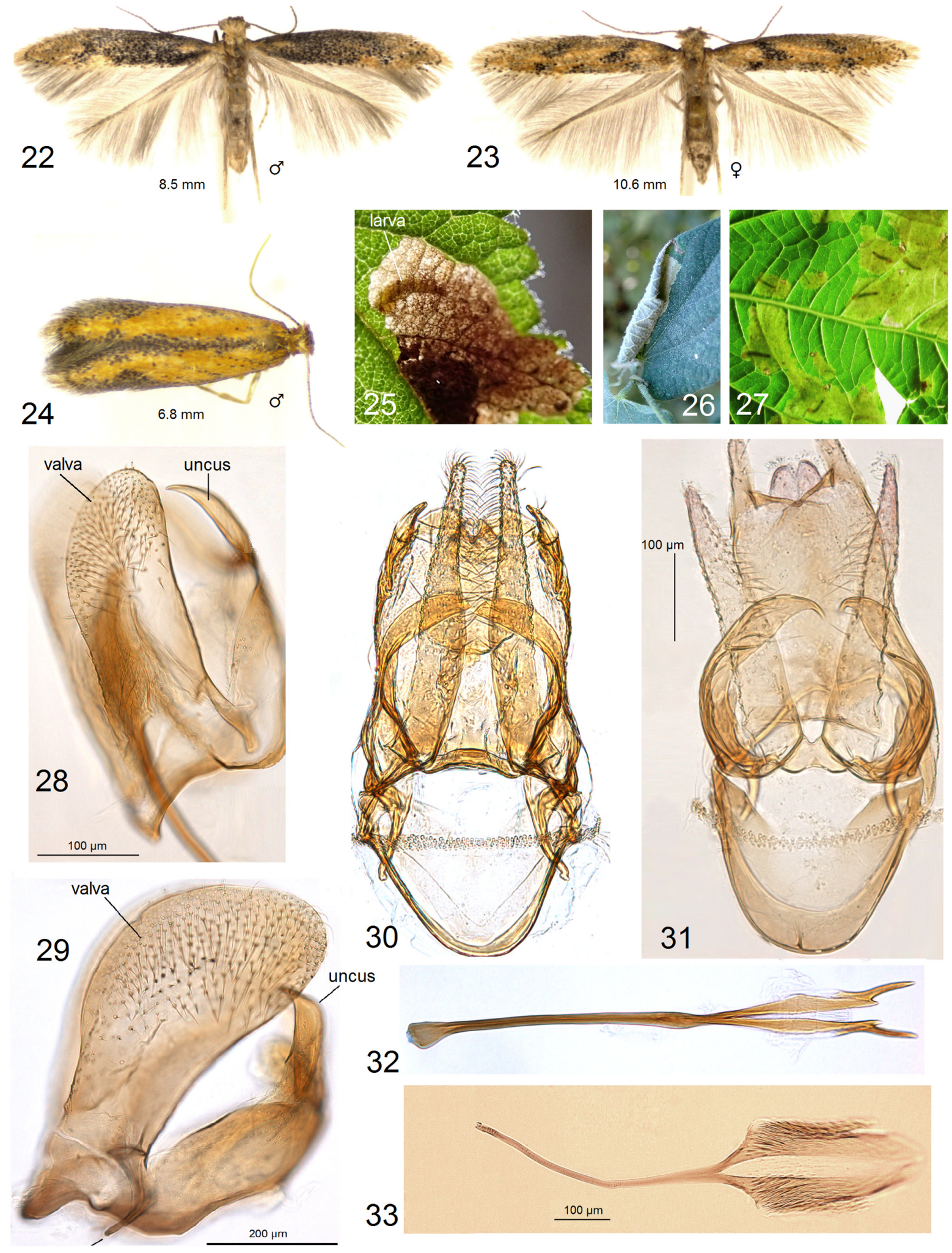

FIGURES 22-33. Tischeriidae, trumpet moths. 22, 23 adults of Astrotischeria chilei Puplesis \& Diškus, 2003, Chile (Stonis et al., 2016a); 24, adult of A. trilobata Diškus \& Stonis, Bolivia; 25, leaf mine of A. plagifera (Meyrick, 1915) on Rhysolepis, Ecuador (Stonis et al. 2018a); 26, same, A. ochrimaculosa Diškus, Stonis \& Vargas, 2019, on Wissadula, Bolivia (Stonis et al., 2019a); 27, same, A. selvica Diškus, Carvalho-Filho \& Stonis on Synedrella (Stonis et al. 2018a); 28, male genitalia, lateral view, Coptotriche carmencita Stonis \& Diškus, Peru; 29, same, C. parvisacculata Diškus \& Stonis, Argentina (Stonis et al. 2019a); 30, same, ventral view, genital capsule, Astrotischeria chilei Puplesis \& Diškus, 2003, Chile (Stonis et al., 2016a); 31, same, A. heliopsisella (Chambers, 1875), California, USA (Stonis et al. 2018a); 32, same, phallus, A. chilei Puplesis \& Diškus, 2003, Chile (Stonis et al., 2016a); 33, same, Coptotriche confusa (Braun, 1972), California, USA (Stonis et al. 2020d) 
Opostegidae biology is relatively obscure (Grossenbacher 1910; Swezey 1921; Kumata 1984; Johansson et al. 1990) and has been summarized by Davis (1989) and Davis \& Stonis (2007), and briefly surveyed by van Nieukerken et al. (2016a). The larvae of some opostegid species have been reported as cambium miners (Kumata 1984, Davis 1989) and as leaf or stem miners (Grossenbacher 1910; Swezey 1921; Johansson et al. 1990; Puplesis \& Diškus 2003).

Tischeriidae, or trumpet moths (Figs 22-33), are known from all continents, except Australia and southernmost South America (and Antarctica). Tischeriidae occur from tropical to temperate regions, but are most abundant in the subtropics and tropics, except in cooler habitats at elevations above 3,600 m (Stonis et al. 2018a). The extraordinary rich fauna of Tischeriidae was recently highlighted from a tropical forest in Central America (Stonis $e t$ al. 2020a). On the other hand, the tischeriid fauna of Southeast Asia and East Asia is also very diverse, but poorly surveyed (Stonis et al. 2014; Kobayashi et al. 2016; Xu et al. 2017, 2018, 2021; Kim et al. 2019), and many new species await discovery. Recently, two Tischeriidae species were reported from Korea (Kim et al. 2019). Adults of Tischeriidae are small, with a wingspan ranging from 6.5 to $7.3 \mathrm{~mm}$. However, some tischeriids are smaller than average with a wingspan of only $4.1 \mathrm{~mm}$, and some are larger than average with a wingspan of $11 \mathrm{~mm}$ (Stonis et al. 2021f). Adults possess various distinctive, diagnostic characters that were reviewed by Braun (1972), Puplesis \& Diškus (2003), Stonis et al. (2018a), Stonis \& Solis (2020), as well as cited by Stonis et al. (2020a, 2021b, 2021c, 2021d, 2021e). Among the most distinctive diagnostic features of the family are the very fine, but strikingly long antennal sensillae trichodea of the male that significantly exceeds the width of the flagellum, and trichodea possess recurved and sometimes thickened bases. The 3rd antennal segment is often greatly enlarged. The frontal tuft is comprised of slender lamellar scales and projected over the triangular or trapezoid frons. In the male genitalia, the phallus is rod-like, and usually bifurcated at the apex or tulip-shaped. In the female genitalia, the round ovipositor lobes are covered with strongly thickened, short, and stout "peg setae"; along the stout anterior and posterior apophyses they possess unique projections in the modified VIIIth and IXth sternites, collectively called prela (after Braun 1972). Larvae of Tischeriidae are predominantly oligophagous or monophagous and mine inside green tissues of plants during all instars, producing blotch-like, irregular (occasionally linear) leaf mines; often, at the final developmental stage, the larva bends or rolls up the margin of the mined leaf. Pupation takes place inside the leaf mine, often in a round, silken-lined nidus.

\section{Material and methods}

We inventoried and counted species in published data worldwide of three monotrysian lepidopteran families: Nepticulidae and Opostegidae (Nepticuloidea), and Tischeriidae (Tischerioidea). We checked and analyzed many original descriptions of species of the above-mentioned families, but the actual data were retrieved from our exhaustive electronic "Global Species Database 1995-2021" maintained by the co-author, Arūnas Diškus. All doubtful synonymies were checked and confirmed by the co-authors J.R. Stonis and A. Diškus and, if the synonymy proved true, the synonymic names were excluded from the current analysis. Species which had been previously documented (described or illustrated), but published unnamed, for example, Acalyptris specimen 12 or A. species AG016 (Stonis et al. 2020c) or Ectoedemia specimen 10 (Wilkinson 1981), were excluded. Taxa published after December 2021 were not included because of the set time range for the current count.

\section{Results and discussion}

\section{Documenting of the global Nepticulidae}

The first species of this family, Ectoedemia occultella, was described in 1767 (Linnaeus 1767). From then on, discoveries and descriptions of Nepticulidae occurred unevenly across 23 time periods (i.e., decades) from 1767 until 2021 (Fig. 34).

After the first species was published, the discovery of new species proceeded very slowly until 1840 , but then starting in 1841 and continuing until 1890, the number of new pygmy moths soared. However, 1881-1900 marked a recession, and then in 1901, a general tendency for an increase in the number of discoveries of new species was observed with slight fluctuations. Two periods clearly stand out: 1971-1980 and especially 2011-2021, during which 
the largest numbers of new species were discovered and described. Understandably, the total, accumulative number of new species of Nepticulidae increased with each time period, but it was particularly apparent during 1971-1980 when the curve of the total number of species rose steeply. During the 255 years of research, 1,000 species were discovered, about 3.92 average species per year. But there is great difference in the average of species described per year between the early 20 th and early 21 st centuries.
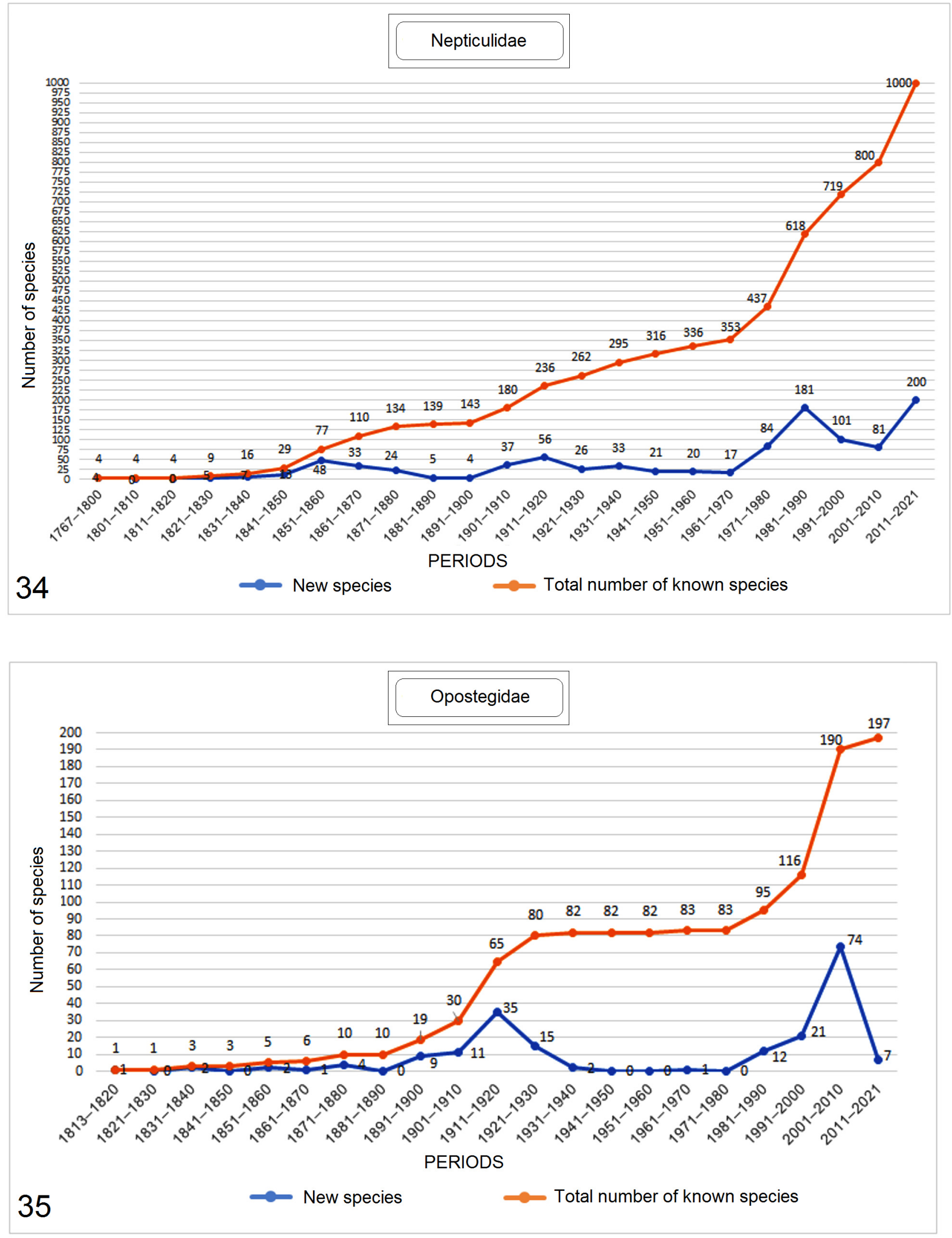

FIGURES 34, 35. Dynamics of species descriptions during various time periods. 34, Nepticulidae; 35, Opostegidae 


\section{Documenting of the global Opostegidae}

The earliest species of the Opostegidae was Pseudopostega auritella, published in 1813, although not yet named as the family Opostegidae at that time (Hübner 1796-1838) (Fig. 35). The analyzed data shows that discoveries of new Opostegidae species were extremely few until the 19th century: a maximum of four described species per time period or decade, or no species described at all. A surge in the number of descriptions was observed at the beginning of the 20th century. In the years 1911-1920 was the highest peak of discovery, when 35 new Opostegidae species were described. From 1931, a sharp decline was observed, which lasted until 1980: only three new species were described during this time period. The total or accumulative number of Opostegidae species gradually increased, and in 1981-1990 there was gradual increase in numbers every decade. The year 1981 opened up significant increase in the number of new species described. In 2001-2010 a record-breaking number of the Opostegidae species were described (74 new species) (Davis \& Stonis 2007; Remeikis et al. 2009). But from 2011, there was a decline once again, when only seven new species were described until 2021. A total of 197 Opostegidae species were published during 209 years of research; an average annual number of species descriptions is 0.94 a year. However, these averages significantly differ in the 19 th century ( 0.22 species per year), the 20 th century ( 0.97 species per year), and the 21 st century (3.86 species per year).

\section{Documenting of the global Tischeriidae}

The first species of the family, Tischeria ekebladella, was described in 1795 (Bjerkander 1795) (Fig. 36). Analysis of the data showed that, starting in 1795 until 1870, the discovery and description of new species proceeded slowly, only a total of 10 new species were described at this early stage of research. During 1871-1880, 15 new species were described, and during 1911-1920, 10 new species. Many new species of Tischeriidae were discovered and published during 1971-1980 (19 species) and 2021-2010 (27 species). The boost in the number of species discoveries occurred in 2011-2021, when 62 new Tischeriidae species were described. The total, accumulative number of described species rose gradually, but it should be noted that the extremely rapid rise occurred at beginning of the 21 st century. A total of 170 Tischeriidae species were described during the 227 years of research, the average number of descriptions per year is 0.75 species. In the 18 th century, the actual annual average was 0.17 species; in the 19 th century it was 0.28 species; in the 20 th century it was 0.52 species; and in the 21 st century it was 4.24 species. It is clear that the annual average was increasing with each century, but a particular increase occurred early in the 21 st century (Fig. 36).

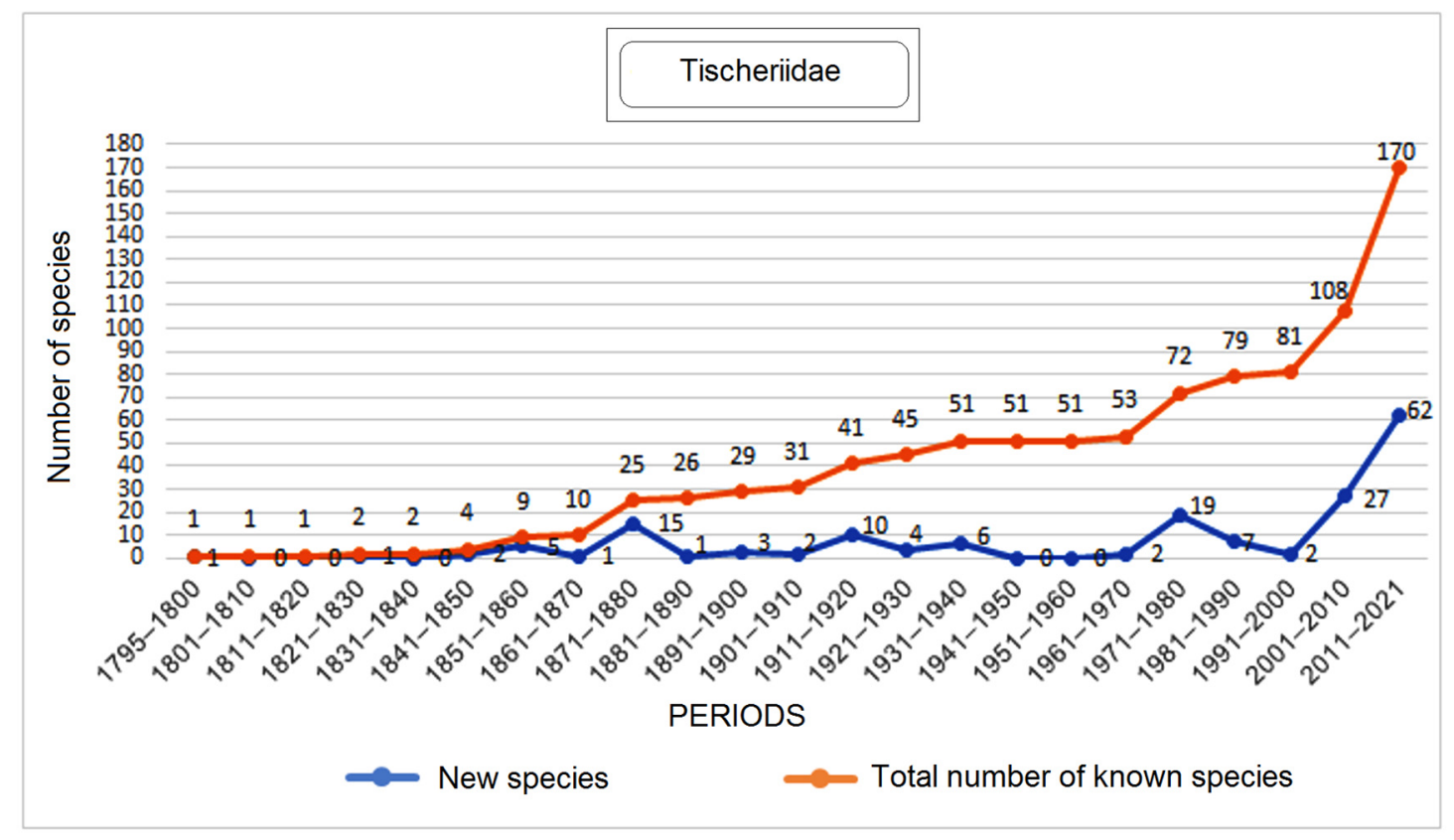

FIGURE 36. Dynamics of Tischeriidae species descriptions during various time periods 

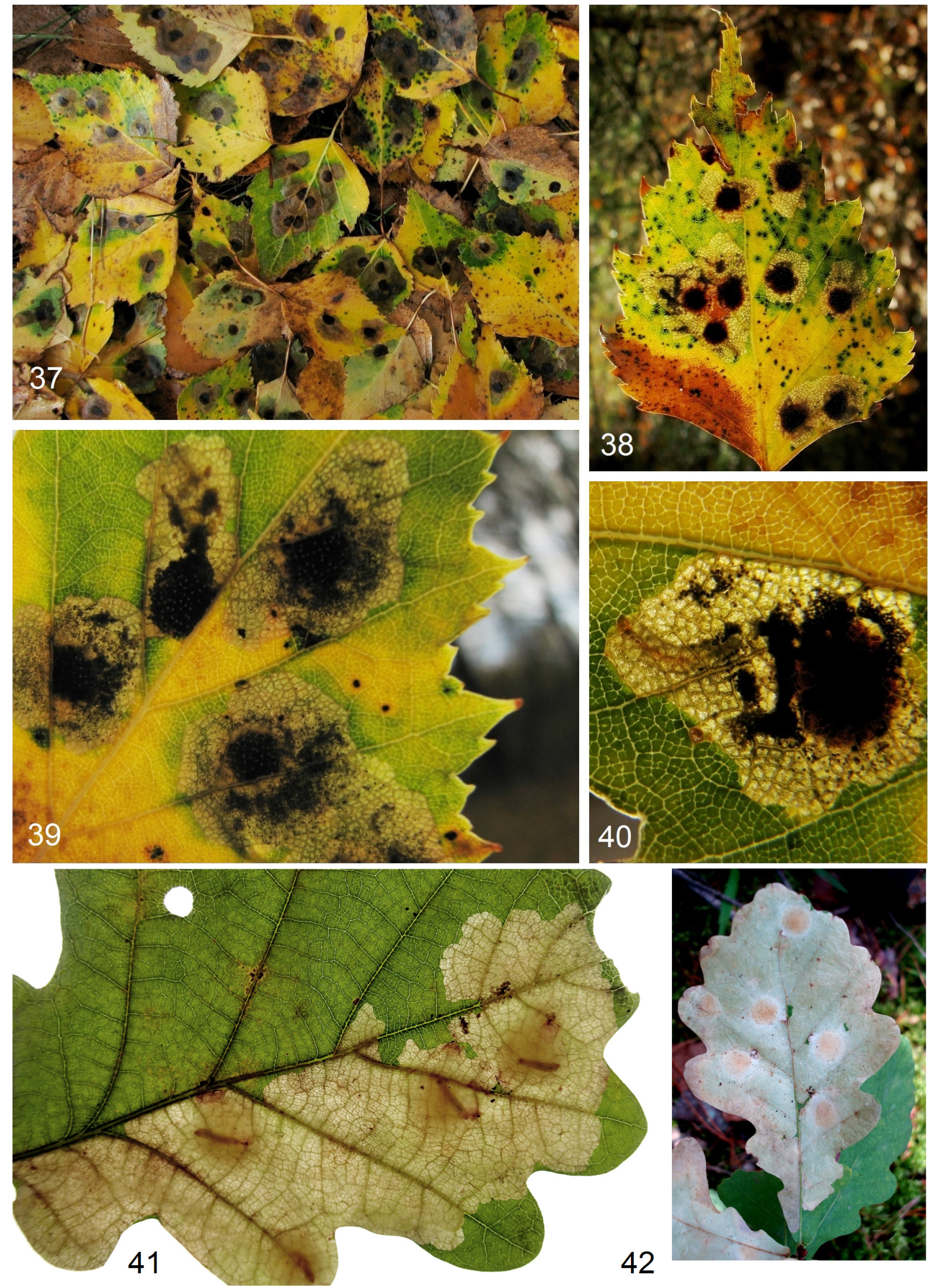

FIGURES 37-42. Leaf mines of the earliest discovered species from Nepticulidae and Tischeriidae. 37-40, Ectoedemia occultella (Linnaeus, 1767), Nepticulidae, leaf mines on Betula pendula; 41, 42, Tischeria ekebladella (Bjerkander, 1795), Tischeriidae, leaf mines on Quercus robur (Note: leaf mines of Pseudopostega auritella (Hübner, 1813), the earliest discovered species of Opostegidae, are still unknown and host-plant data are doubtful; see Johansson et al. 1990) 


\section{Authors or groups of authors who described Nepticulidae}

Our inventory of primary descriptions found 147 authors or various groups of authors associated with descriptions of new Nepticulidae species. Thus, the average for a single author, or a group of authors, is 6.81 described species. In fact, the majority of the authors described fewer. In total, 79 authors or groups of authors described a single Nepticulidae species each: Amsel; Bedell; Boheman; Borkowski; Bradley; Capuse; Chen \& Wang; Diškus, Navickaite \& Remeikis; Diškus, Remeikis \& Stonis; Doubleday; Dugdale; Fabricius; Fologne; Forbes \& Leonard; Freeman; Frey \& Boll; Göze; Gregor \& Pavolný; Groschke; Hartig; Heyden; Hoare \& van Nieukerken; Hofmann; Hübner; Hudson; Jones; Kearfott; Kollar; A. Laštuvka \& Huemer; Z. Laštůvka, A. Laštůvka \& Johansson; Larsen; Le Marchand; Legrand; Linnaeus; Mariani; Minet; Müller-Rutz; Nieukerken van \& Berggren; Nieukerken van, van den Berg \& Hoare; Nieukerken van \& Hull; Nieukerken van \& Ivinskis; Nieukerken van \& Puplesis; Nieukerken van \& Snyers; Nieukerken van \& van den Berg; Nieukerken van, Z. Laštůvka \& A. Laštůvka; Parenti; Peyerimhoff; Petry; Puplesis \& Krasilnikova; Puplesis, Diškus \& Juchnevich; Puplesis, Diškus \& Nieukerken van; Remeikis; Remekis \& Dobrynina; Richardson; Sato; Schleich; Sircom; Snellen; Soffner; Staudinger; Stonis; Stonis \& Remeikis; Stonis, Diškus \& Remeikis; Svensson; Tengström; Tokár, A. Laštůvka \& Nieukerken van; Toll; Tutt; Wagner; Walker; Waters; Watt; Wilson; Wolff; Wood; Wood \& Walsingham; Wörz; Yagi \& Hirowatari; and Zetterstedt.

In total, 15 authors or groups of authors described two species each: Bourquin; Caradja; Duponchel; Falkovitsh; Gerasimov; Glitz; A. Laštůvka, Z. Laštůvka \& Nieukerken van; Nieukerken van \& Hoare; Philpott; Preissecker; Rebel; Remeikis, Diškus \& Stonis; Skala; Szöcs; and Weber.

The following 10 authors or groups of authors described three new species each: Joannis; Kuroko; Z. Laštůvka, A. Laštůvka \& Nieukerken van; Matsumura; Mendes; Nel \& Varenne; Stonis \& Vargas; Šimkevičiūtė \& Stonis; Wilkinson; and Zimmermann.

The following five authors or groups of authors are responsible for the description of four new species each: Busck; Johansson, Nieukerken van \& Liu; Nieukerken van, A. Laštůvka \& Z. Laštůvka; and Wilkinson \& Scoble.

Our graphs (Fig. 43) include only authors or groups of authors who described a significant number of new species, i.e., at least five. However, the number of described species varies significantly among authors, and therefore, the following gradation was introduced: $<20, \geq 20$, and $\geq 40$ described species. The data showed that, among the authors or groups of authors who significantly contributed to the description of global fauna, authors or groups of authors who described fewer than 20 new species prevailed ( 26 authors of groups of authors). Meanwhile, $\geq 20$ new species were described by seven authors or groups of authors, and $\geq 40$, by six authors or groups of authors (Fig. 43).

\section{Contribution of individual researchers to the description of the global Nepticulidae}

A total of 131 individual researchers participated in the taxonomic inventory of the global Nepticulidae fauna. By plotting the researchers who made the largest contribution (Fig. 44), 39 authors who described at least five Nepticulidae species were selected and included. As in the case above, the number of the described species varies significantly among various authors; therefore, the following gradation was introduced: $<20, \geq 20$, and $\geq 40$ described species. The data showed 24 researchers who described $<20$ new species. Six researchers described $\geq 20$ new species, and nine researchers participated in the description of $\geq 40$ species. According to our data, the following authors made exceptional contributions to the taxonomic inventory of global Nepticulidae: J. R. Stonis (329 new species), A. Diškus (123 species), M. J. Scoble (77 species), E. Meyrick (69 species), E. J. van Nieukerken (69 species), A. Remeikis (67 species), Ch. Wilkinson (49 species), A. Laštůvka (44 species), and Z. Laštůvka (42 species) (Fig. 44).

\section{Contribution of individual researchers to the description of global Opostegidae}

In total, 27 authors or groups of authors are responsible for the description of Opostegidae species globally. Unlike Nepticulidae, the execution of Opostegidae descriptions was less active with fewer researchers participating in the describing and naming of species. Most of the authors or groups of authors (22 total) described fewer than five new 
species each. Meanwhile, three authors or groups of authors described $\geq 5$ new species, and only two, $\geq 50$ (Fig. 45).

With regard to individual contributions by researchers, the following three researchers have made the largest contributions to the global inventory based on number of described species: J. R. Stonis (99 species), D. R. Davis (75 species), and E. Meyrick (52 species) (Fig. 46).

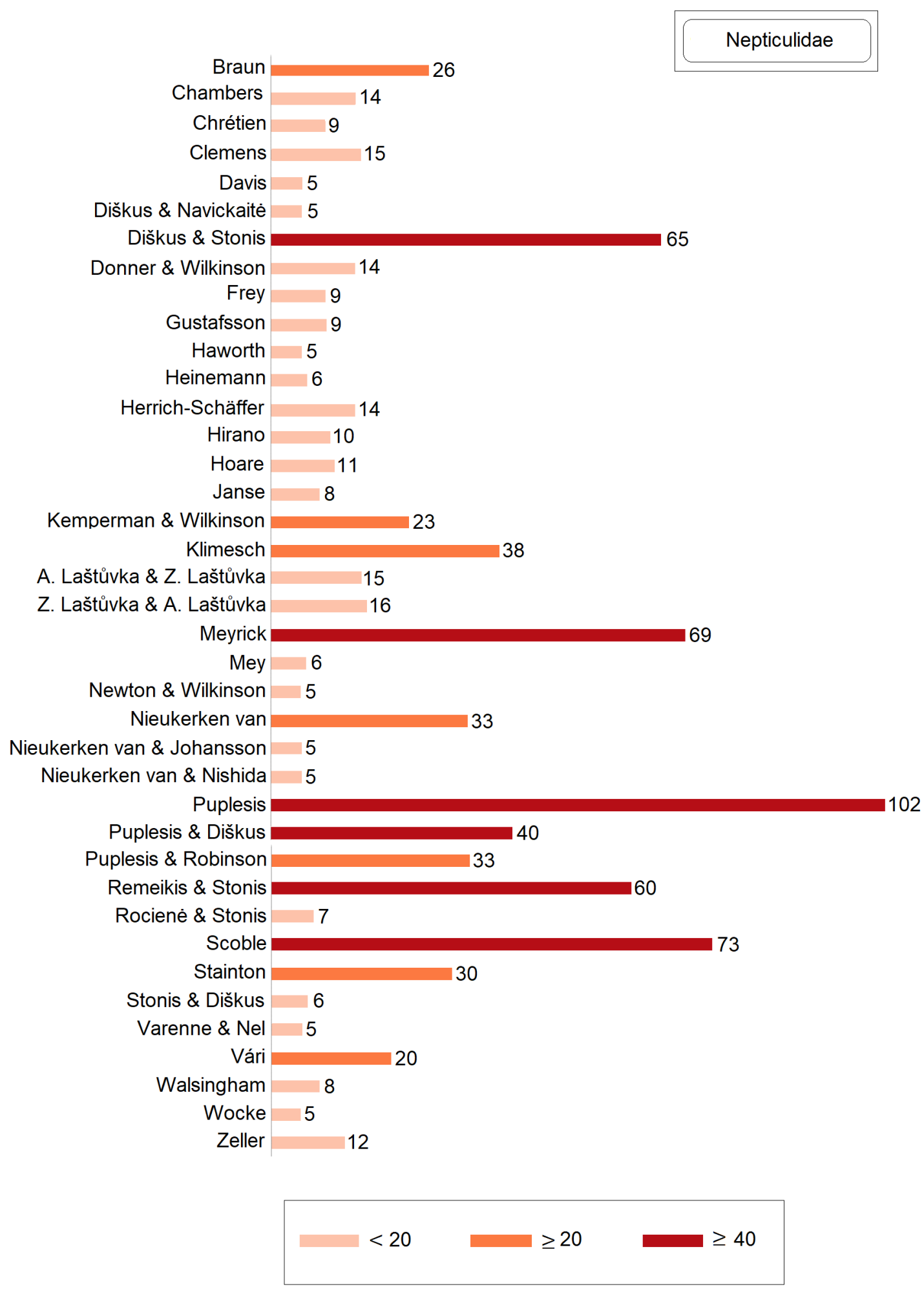

FIGURE 43. Authors or groups of authors who made a significant contribution to the description of global fauna of Nepticulidae and described at least five new species 
Braun, A. F.

Chambers, V. T. 14

Chrétien, $\mathrm{P}$. $\quad 9$

Clemens, M. D. $\quad 15$

Davis, D. R. 5

Diškus, A.

Donner, $\mathrm{H}$. 14

Frey, $\mathrm{H}$. 10

Gustafsson, B. $\quad 9$

Haworth, A. H. 5

Heinemann, $\mathrm{H}$. 6

Herrich-Schäffer, G. A. W. 14

Hirano, N. 10

Hoare, R. J. B. 15

Janse, A. J. T. 8

Johansson, R. $\quad 10$

Kemperman, T. C. M. 23

Klimesch, J. 38

Laštuvka, A. 44

Laštuvka, Z. 42

Mey, W. 6

Meyrick, E. 69

Navickaitè, A. 6

Nel, J. $\quad 8$

Newton, P. J. 5

Nieukerken van, E. J. 69

Nishida, K. 5

Remeikis, A. 68

Robinson, G. S. 33

Rocienè, A. 7

Scoble, M. J.

$\begin{array}{lll}\text { Stainton, H. T. } & 30 & 329\end{array}$

Stonis, J. R. (=Puplesis)

Varenne, T. 8

Vári, L. 20

Walsingham, T. G. $\quad 9$

Wilkinson, C. 49

Wocke, M. F. 5

Zeller, P. C. $\quad 12$

\section{$<20 \geq 20 \quad \geq 40$}

FIGURE 44. Individual researchers who contributed the most to discovery and description of the Nepticulidae global fauna. (Note: graph does not include researchers who described fewer than five new species 


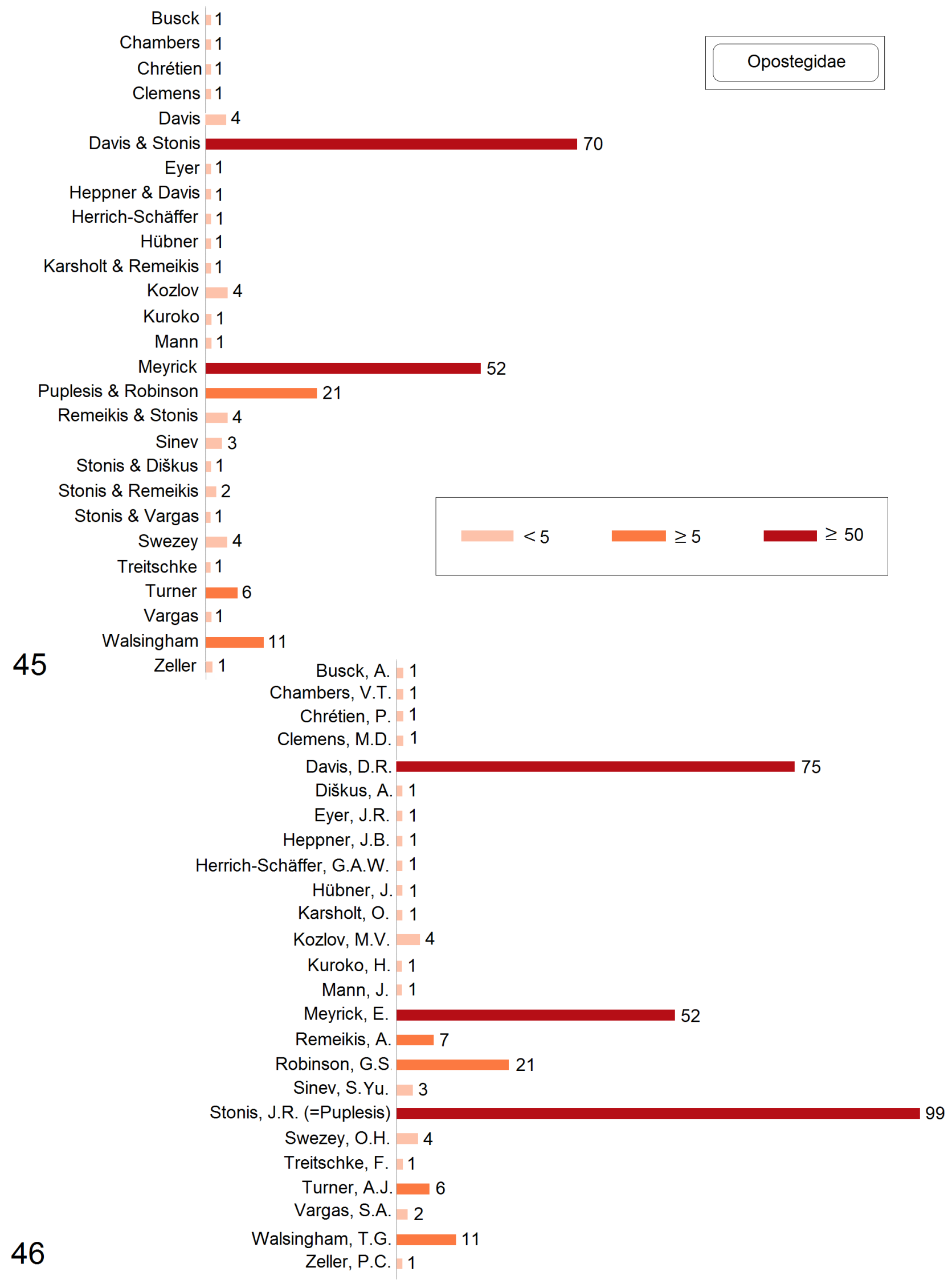

FIGURES 45, 46. Description of the global Opostegidae. 45, authors or groups of authors who described new species; 46, Individual contributions by researchers to descriptions 


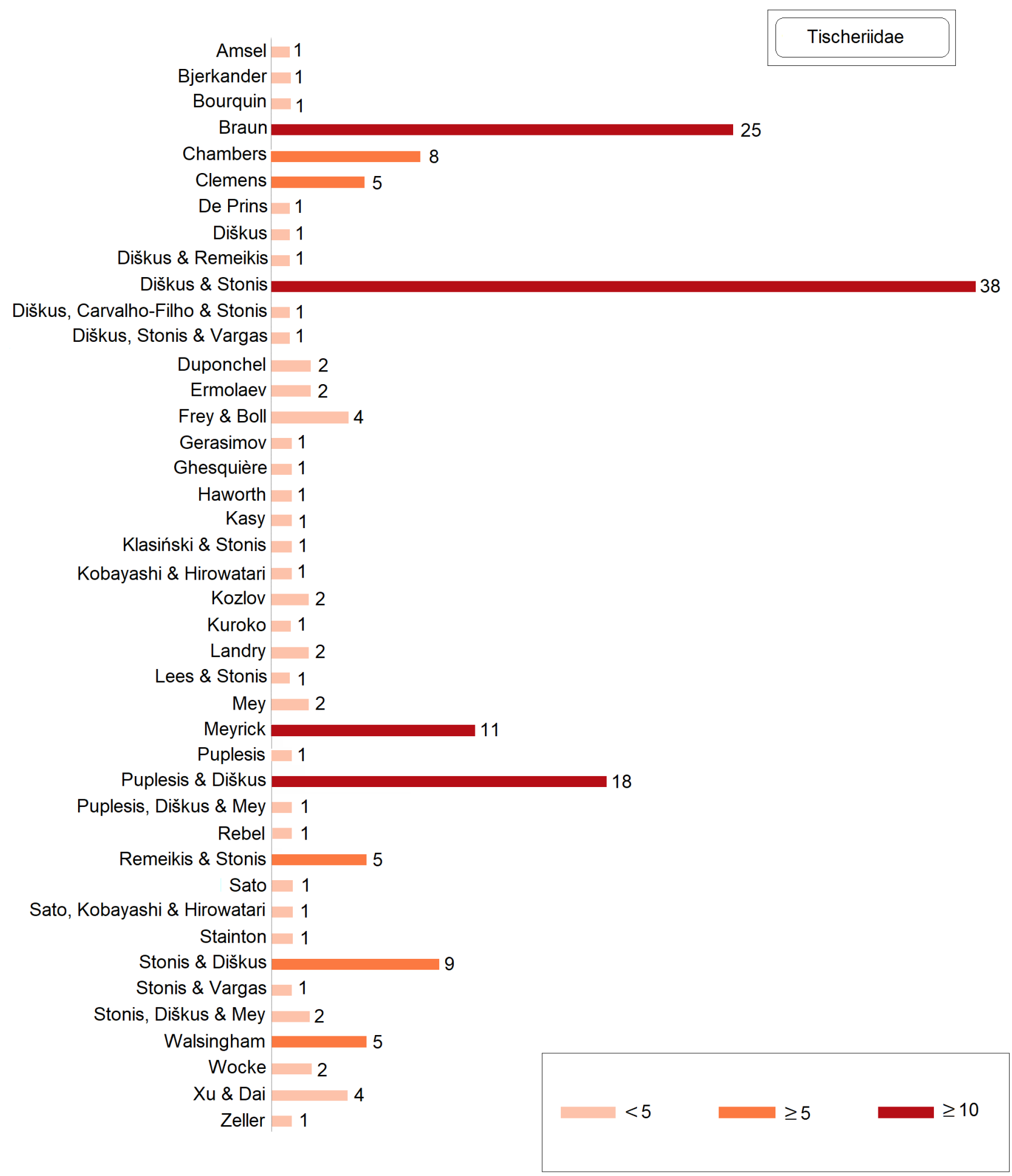

FIGURE 47. Authors or groups of authors associated with Tischeriidae species descriptions globally

\section{Contribution of individual researchers to the description of global Tischeriidae}

Taxonomic studies of Tischeriidae were performed by 38 authors or groups of authors. There were three groups according to the number of described species: $<5, \geq 5$, and $\geq 10$. Most of these authors (33) described fewer than five new species each. Meanwhile, five authors described $\geq 5$ new species and four authors described $\geq 10$ new species (Fig. 47). 
With regard to the contribution of individual researchers, the following researchers have made the greatest contributions to the global inventory based on numbers of described species: J. R. Stonis (79 species), A. Diškus (72 species) A. F. Braun (25 species), and E. Meyrick (11 species) (Fig. 48). Most of the researchers (28) are responsible for the description of fewer than five species each, and some, for five to eight species.

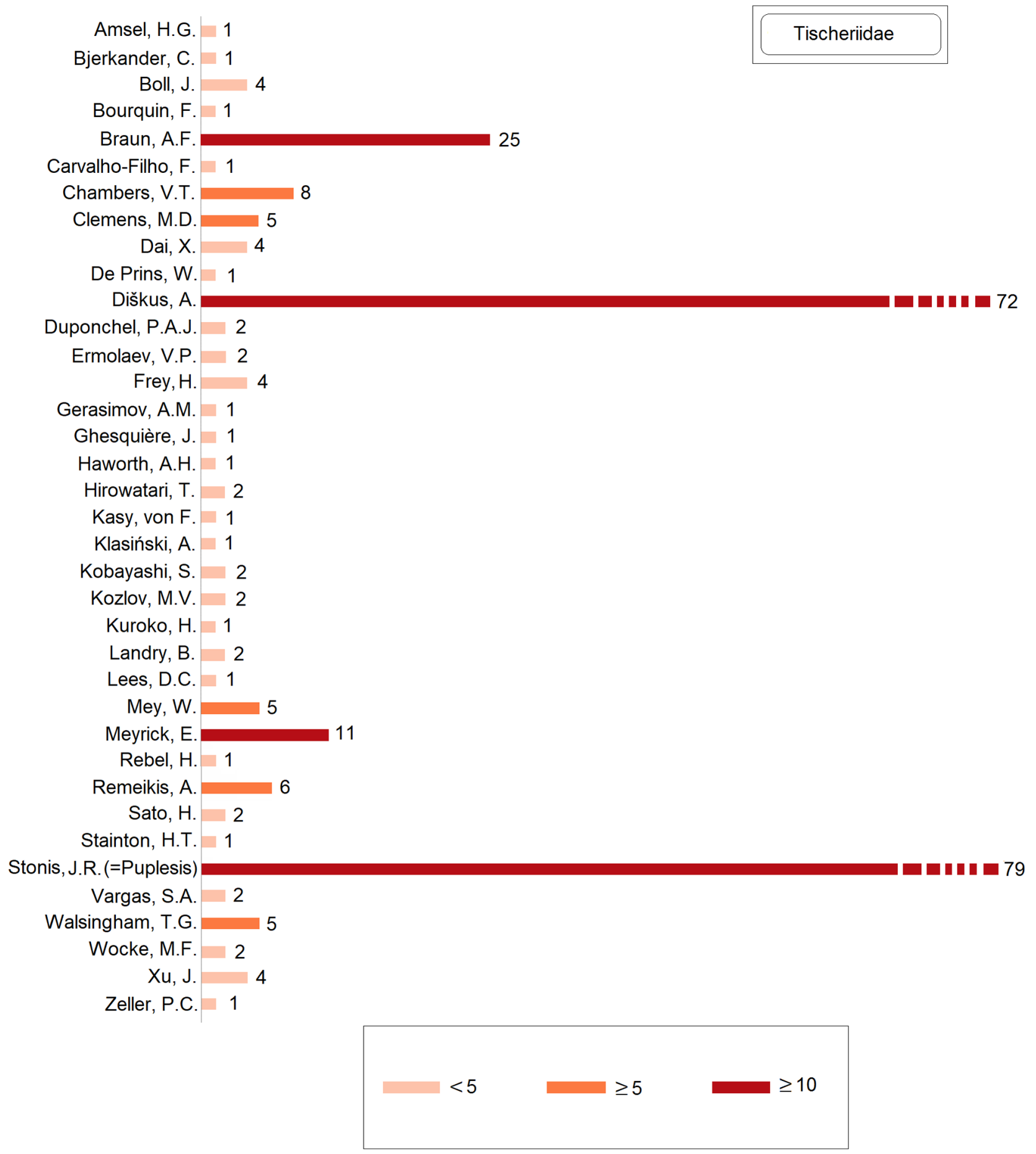

FIGURE 48. Contribution of individual researchers to the discovery and description of global Tischeriidae

\section{Discussion}

Upon summarizing studies in all three families and contributions of individual researchers, we found that eight researchers were responsible for $\geq 30$ new species descriptions, and six researchers for $\geq 70$ species descriptions. Here, we single out researchers whose contributions to the description of species was the greatest: M. J. Scoble 
described 77 species, D. R. Davis and A. Remeikis described 80 species each, E. Meyrick described 132 species, A. Diškus described 196 species, and J.R. Stonis discovered and described a record-breaking number of 507 species (Fig. 49).

Nepticulidae + Opostegidae + Tischeriidae
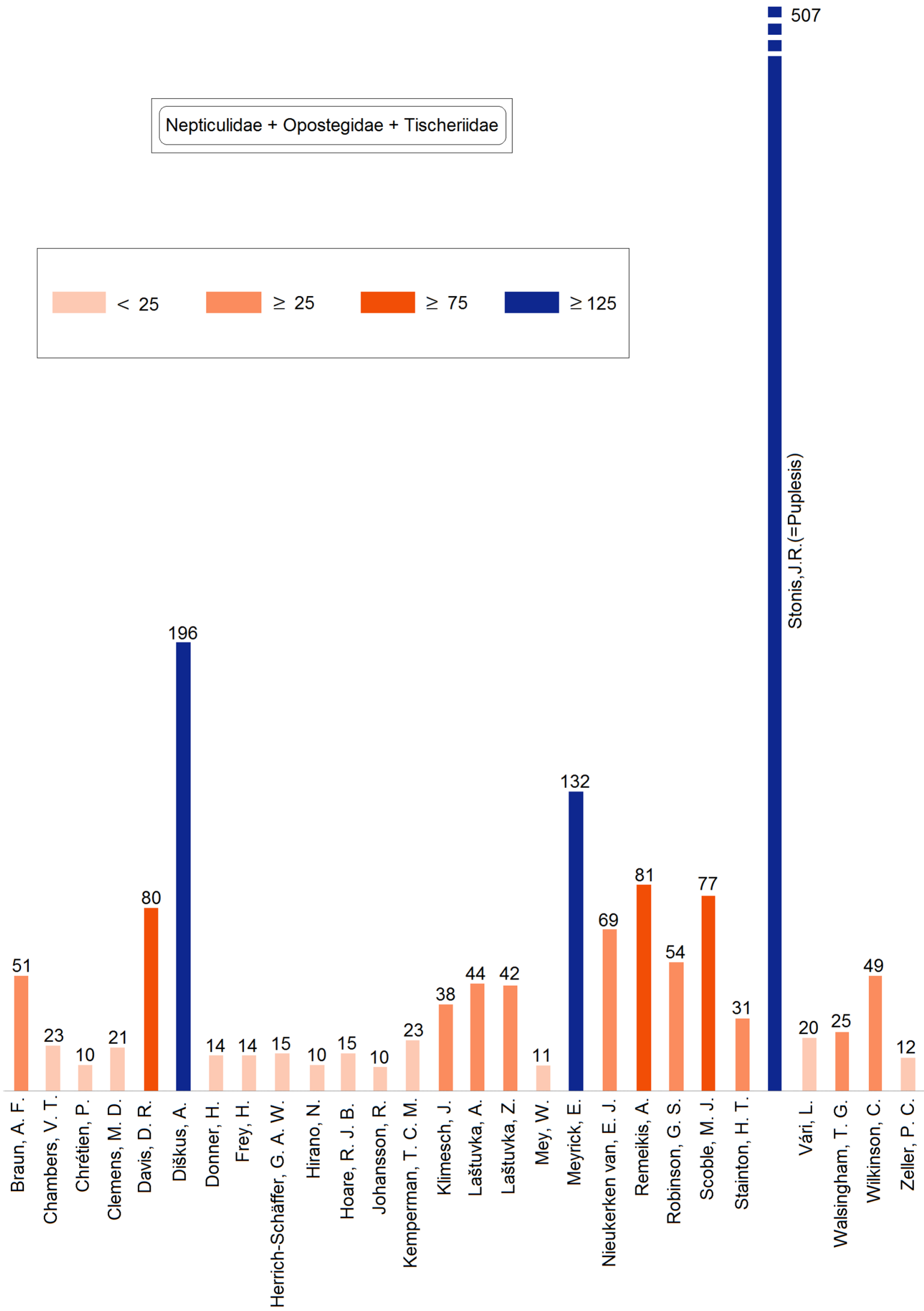

FIGURE 49. Contribution of individual researchers to the discovery and description of the three analyzed families (Nepticulidae, Opostegidae, and Tischeriidae) (Note: graph includes only researchers who described at least 10 new species) 


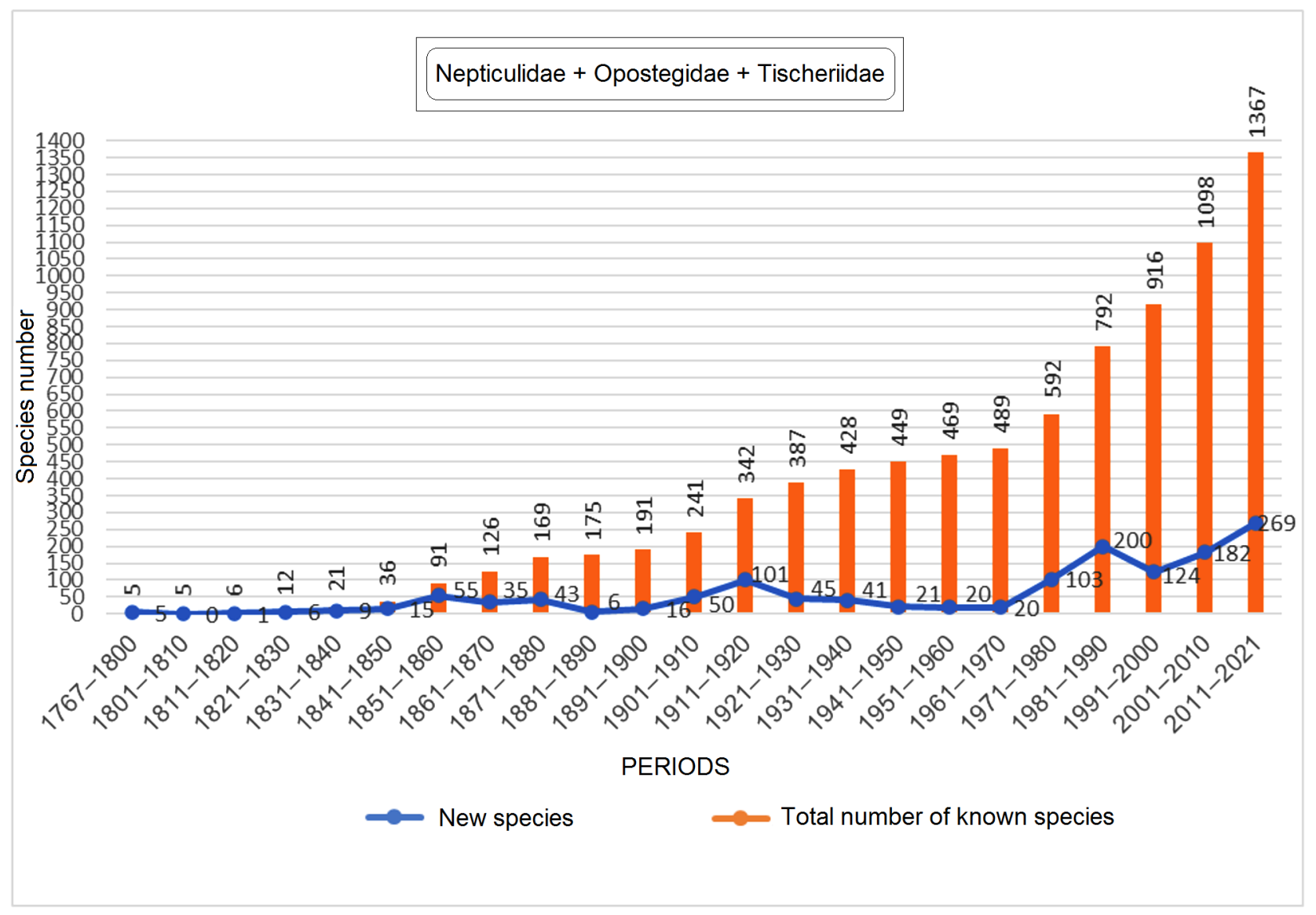

FIGURE 50. Species description dynamics of the three analyzed families (Nepticulidae, Opostegidae, and Tischeriidae) over various time periods.

With regard to the 255-year research history in the three families, there was a significant increase in taxonomic inventory in the early 20 th century and especially in the late 20 th - early 21 st centuries. The total or accumulative number of species of the three analyzed families increased with each period, and is now 1,367 species globally (with an overall average of about five new species described per year, or about 22 new species described per year in the 21st century).

But this is not the last word on the discovery and documentation of new taxa in these three families of leafmining moths. Targeted studies are currently underway to elucidate the taxonomic diversity of Korean Nepticulidae. Although no new species have been identified in our studies, the silver lining in the material suggests that the fauna of the Nepticulidae of the Korean Peninsula is akin to the fauna of the surrounding areas. Most of the species from Korea were previously described by R. Puplesis from the Primorye Territory in Far Eastern Russia (Puplesis 1984a, 1984b, 1984c, 1984d, 1985; Puplesis \& Ivinskis 1985, with further re-examination and illustration by Stonis \& Rocienè 2013 and Rocienè \& Stonis 2013): Stigmella aladina Puplesis, 1984; S. dentatae Puplesis, 1984; S. kurokoi Puplesis, 1984; S. omelkoi Puplesis, 1984; Bohemannia nubila Puplesis, 1985; Etainia capesella (Puplesis, 1985); E. peterseni (Puplesis, 1985); E. sabina (Puplesis, 1985) (Lee \& Byun 2007; Shin et al. 2020, 2022). Two species recently discovered in Korea were previously known from Japan: Stigmella fumida Kemperman \& Wilkinson, 1985, and Etainia trifasciata (Matsumura, 1931) (Lee \& Byun 2007; Shin et al 2022). The latter species, E. trifasciata (=E. tigrinella Puplesis, 1985), was also known from Far Eastern Russia (Puplesis \& Ivinskis 1985; Puplesis 1994; Puplesis \& Diškus 2003; Hirano 2013). A broader perspective with these preliminary results indicates that the fauna of East Asian Nepticulidae is just the tip of the iceberg, and, in the future, many species new to science will be discovered in the Asian continent, including China, Japan, and Korea. 


\section{Acknowledgements}

We thank Dr. Andrius Remeikis and Dr. Jolanta Rimšaite (Nature Research Centre, Lithuania) for their generous help provided during the prepration of the manuscript. We are grateful to Prof. Dr. Bong-Kyu Byun, Science Editor of Zootaxa, for the managing the editorial process and suggestions. We also thank reviewers Prof. Dr. Liliana Katinas (University of La Plata, Argentina) and Dr. Oleksiy Bidzilya (Institute for Evolutionary Ecology, National Academy of Sciences of Ukraine) for their overview and remarks.

This research was partially funded by a grant (S-MIP-19-30, "DiagnoStics") from the Research Council of Lithuania.

The study by S.V. Baryshnikova was performed within the State research project 1021051302540-6.

M. Alma Solis thanks Dr. Michael Gates, Research Leader, of the Systematic Entomology Laboratory, ARS, USDA, for supporting the participation of MAS in this research. Mention of trade names or commercial products in this publication is solely for the purpose of providing specific information and does not imply recommendation or endorsement by USDA. USDA is an equal opportunity provider and employer.

\section{References}

Bai, H. \& Li, H. (2009) Review of Spulerina (Lepidoptera: Gracillariidae) from China, with description of three new species. Oriental Insects, 43 (1), 33-44. https://doi.org/10.1080/00305316.2009.10417573

Bai, H., Xu, J. \& Dai, X. (2015) Three new species, two newly recorded species and one newly recorded genus of Lithocolletinae (Lepidoptera: Gracillariidae) from China. Zootaxa, 4032 (2), 229-235. https://doi.org/10.11646/zootaxa.4032.2.10

Bai, H., Xu, J. \& Dai, X. (2016) Two new and one newly recorded species of Gracillariidae from China (Lepidoptera). Zookeys, $559,139-150$. https://doi.org/10.3897/zookeys.559.6812

Baryshnikova, S.V. (2001) New species of bucculatricid moths from Nepal (Lepidoptera: Bucculatricidae). Zoosystematica Rossica, 10 (1), 167-170.

Baryshnikova, S.V. (2005) New and little-known Asian species of the genus Bucculatrix Z. (Lepidoptera, Bucculatricidae) and their taxonomic attribution. Entomologicheskoe Obozrenie, 84, 377-386. [in Russian]

Baryshnikova, S.V. (2007) Two new Palaearctic species of the genus Bucculatrix (Lepidoptera, Bucculatricidae). Zoosystematica Rossica, 16 (2), 285-288.

Baryshnikova, S.V. (2013) A new remarkable species of the genus Bucculatrix (Lepidoptera: Bucculatricidae) from the Primorsky Territory (Russian Far East). Zoosystematica Rossica, 22 (1), 111-113. https://doi.org/10.31610/zsr/2013.22.1.111

Bjerkander, C. (1795) Phalaena Ekebladella en ny Nattfjáril belkrifven. Kungliga Svenska Vetenskapsakademiens Handlingar, $16,58-63$.

Braun, A.F. (1972) Tischeriidae of America North of Mexico (Microlepidoptera). Memoirs of the American Entomological Society, 28, 1-148.

Brito, D. (2010) Overcoming the Linnean shortfall: Data deficiency and biological survey priorities. Basic and Applied Ecology, 11 (8), 709-713. https://doi.org/10.1016/j.baae.2010.09.007

Brito, R., Lopez-Vaamonde, C., Gonçalves, G.L., Becker, V.O., Mielke, O.H.H. \& Moreira, G.R.P. (2017) Taxonomic revision of Neotropica; Phyllocnistis Zeller, 1848 (Lepidoptera, Gracillariidae), with descriptions of seven new species and host plant associations. Zootaxa, 4341 (3), 301-352.

Ceballos, G., Ehrlich, P.R. \& Dirzo, R. (2017) Biological annihilation via the ongoing sixth mass extinction signaled by vertebrate population losses and declines. PNAS, 114 (30), E6089-E6096. https://doi.org/10.1073/pnas.1704949114

Crisci, J., Katinas, L., Apodaca, M.J. \& Hoch, P.C. (2020) The end of Botany. Trends in Plant Science, 25 (12), $1173-1176$. https://doi.org/10.1016/j.tplants.2020.09.012

Cutko, A. (2009) Biodiversity Inventory of Natural Lands: A How-To Manual for Foresters and Biologists. NatureServe, Arlington, Virginia, $32 \mathrm{pp}$. https://www.natureserve.org/sites/default/files/biodiversityinventorymanual_main.pdf

Davis, D.R. (1986) A new family of monotrysian moths from austral South America (Lepidoptera: Palaephatidae), with a phylogenetic review of the Monotrysia. Smithsonian Contributions to Zoology, 434, 1-202. https://doi.org/10.5479/si.00810282.434

Davis, D.R. (1989) Generic revision of the Opostegidae, with a synoptic catalog of the world's species (Lepidoptera: Nepticu- 
loidea). Smithsonian Contributions to Zoology, 478, 1-97.

https://doi.org/10.5479/si.00810282.478

Davis, D.R., Landry, B. \& Roque-Albelo, L. (2002) Two new Neotropical species of Bucculatrix leaf miners (Lepidoptera: Bucculatricidae) reared from Cordia (Boraginaceae). Revue suisse de Zoologie, 109 (2), 277-294. https://doi.org/10.5962/bhl.part.79591

Davis, D.R. \& Stonis, J.R. (2007) A revision of the New World plant-mining moths of the family Opostegidae (Lepidoptera: Nepticuloidae). Smithsonian Contributions to Zoology, 625, i-v+212. https://doi.org/10.5479/si.00810282.625

Davis, J. (2020) Armoured 'slug' among 503 new species described by Museum scientists in 2020. Available from: https://www. nhm.ac.uk/discover/news/2020/december/503-new-species-described-by-museum-scientists-in-2020.html (accessed 5 December 2021)

De Prins, J. \& De Prins, W. (2012-2021) Global taxonomic database of Gracillariidae. Royal Museum for Central Africa \& Belgian Biodiversity Platform. Available from: http://www.gracillariidae.net (accessed 3 December 2021)

De Prins, J. \& Kawahara, A.Y. (2012) Systematics, revisionary taxonomy, and biodiversity of Afrotropical Lithocolletinae (Lepidoptera, Gracillariidae). Zootaxa, 3594 (1), 1-283. https://doi.org/10.11646/zootaxa.3594.1.1

Diškus, A. \& Stonis, J.R. (2012) Leaf-mining insects of Lithuania. The Nepticulidae (Lepidoptera): taxonomy, chorological composition and trophic relationships. Monograph. Lutute Publishers, Kaunas, 220 pp. [in Lithuanian]

Dobrynina, V., Baryshnikova, S., Budrys, E., Rimšaite, J. \& Bidzilya, O. (2021) Taxonomic papers as published products of the biodiversity inventory: if not the Impact Factor (IF) or Quartiles (Q), then what determines their importance estimated on the basis of the Research Interest Score? Biologija, 67 (2), 93-113.

https://doi.org/10.6001/biologija.v67i2.4454

Doorenweerd, C., Nieukerken, E.J. van \& Hoare, R.J.B. (2016) Phylogeny, classification and divergence times of pygmy leafmining moths (Lepidoptera: Nepticulidae): the earliest lepidopteran radiation on Angiosperms? Systematic Entomology, 42, 267-287. https://doi.org/10.1111/syen.12212

Dubois, A. (2011) Describing a New Species. TAPROBANICA The Journal of Asian Biodiversity, 2 (1), 6-24. https://doi.org/10.4038/tapro.v2i1.2703

Ermolaev, V.P. (1977) A review of the fauna and ecology of miner-moths (Lepidoptera, Gracillariidae) of the Primorye Territory. The Fauna of Insects of the Far East. Trudy Zoologicheskogo Instituta, Akademija Nauk SSSR, 70, 98-116. [in Russian]

Ermolaev, V.P. (1981) New species of gracillariid mining moths (Lepidoptera, Gracillariidae) from the Far East. Systematics and Zoogeography of the Lepidoptera of the Asiatic Part of the USSR. Trudy Zoologicheskogo Instituta, Akademija Nauk SSSR, 103, 84-88. [in Russian]

Ermolaev, V.P. (1986) New and little-known species of leafblotch miners (Lepidoptera, Gracillariidae) from the south of Primorye Territory. Entomologicheskoe Obozrenie, 65 (4), 741-752. [in Russian]

Eyer, J.R. (1966) Melanic moths of the genus Opostega (Tineoidea). Journal of the Lepidopterists' Society, 20 (4), $232-234$.

Gerasimov, A. (1930) Neue und wenig bekannte palaearktische Microheterocera I. Deutsche Entomologische Zeitschrift "Iris", $44(3), 132-135$.

Gerasimov, A.M. (1931) Zur Lepidopteren-fauna von Mittelasien III. Neue Lithocolletis. Entomologische Zeitschrift, 45 (9), $125-132$.

Gerasimov, A.M. (1933) Minierende Motten. III. Neue auf Rosacean lebende Lithocolletis-Arten (Lep., Gracil.). Deutsche Entomologische Zeitschrift "Iris", 47, 119-122.

Grossenbacher, J.G. (1910) Medullary spots: a contribution to the life history of some cambium miners. New York Agricultural Experiment Station Technical Bulletin, 15, 49-65.

Hawksworth, D.L. (2011) Biodiversity and conservation of insects and other invertebrates. Biodiversity and Cnservation, 20 , 2863-2866. https://doi.org/10.1007/s10531-011-0178-x

Hirano, N. (2013) Nepticulidae. In: Hirowatari, T., Nasu, Y., Sakamaki, Y. \& Kishida, Y. (Eds.), Nihon-san garui hyojun zukan (The standard of moths in Japan). Gakken Kyoiku Shuppan, Tokyo, pp. 80-96, pls. 3-03-3-06. [in Japanese]

Hortal, J., de Bello, F., Diniz-Filho, J.A.F., Lewinsohn, T.M., Lobo, J.M. \& Ladle, R.J. (2015) Seven shortfalls that beset largescale knowledge of biodiversity. Annual Review of Ecology Evolution and Systematics, 46, 523-549. https://doi.org/10.1146/annurev-ecolsys-112414-054400

Hübner, J. (1796-1838) Sammlung europäischer Schmetterlinge. 8. Tineae. 1 volume of text \& 8 volumes of plates. Verfasser, Augsburg. [unknown pagination]

Johansson, R., Nielsen, E.S., Nieukerken, E.J. van \& Gustafsson, B. (1990) The Nepticulidae and Opostegidae (Lepidoptera) of north west Europe. Fauna Entomologica Scandinavica, 23 (1/2), 1-739.

Kawahara, A., Nishida, K. \& Davis, D.R. (2009) Systematics, host plants, and life histories of three new Phyllocnistis species from the central highlands of Costa Rica (Lepidoptera, Gracillariidae, Phyllocnistinae). ZooKeys, 27, 7-30. https://doi.org/10.3897/zookeys.27.250

Kim, H.-K., Bayarsaikhan, U., Na, S.-M., Lee, D.-J., Ko, J.-H., Lee, T.-G., Cha, Y.-B., Jang, C.-M. \& Bae, Y.-S. (2019) Two newly recorded species of Tischeriidae (Lepidoptera: Tischerioidea) from Korea. Journal of Asia-Pacific Biodiversity, 12 
(2), 273-277.

https://doi.org/10.1016/j.japb.2018.12.001.

Kirichenko, N., Triberti, P., Kobayashi, S., Hirowatari, T., Doorenweerd, C., Ohshima, I., Huang, G.-H., Wang, M., Magnoux, E. \& Lopez-Vaamonde, C. (2018) Systematics of Phyllocnistis leaf-mining moths (Lepidoptera, Gracillariidae) feeding on dogwood (Cornus spp.) in Northeast Asia, with the description of three new species. ZooKeys, 736, 79-118. https://doi.org/10.3897/zookeys.736.20739

Kirichenko, N., Triberti, P. \& Lopez-Vaamonde, C. (2019) New species of leaf-mining Phyllonorycter (Lepidoptera Gracillariidae) from Siberia feeding on Caragana (Fabaceae). ZooKeys, 835, 17-41. https://doi.org/10.3897/zookeys.835.33166

Kobayashi, S., Hirowatari, T. \& Kuroko, H. (2010) A revision of Japanese species of the family Bucculatricidae (Lepidoptera). Transactions of the Lepidopterological Society of Japan, 61 (1), 1-57. https://doi.org/10.18984/lepid.61.1_1

Kobayashi, S., Sato, H., Hirano, N., Yamada, K. \& Hirowatari, T. (2016) A review of the Japanese species of the family Tischeriidae (Lepidoptera). ZooKeys, 601, 127-151. https://doi.org/10.3897/zookeys.601.7782

Kristensen, N.P. \& Skalski, A.W. (1999) Phylogeny and Palaeontology. In: Kristensen, N.P. (Ed.), Lepidoptera, Moths and Butterflies. Part 35. Vol. 1. Evolution, Systematics, and Biogeogaphy, Handbook of Zoology. Vol. IV. Arthropoda, Insecta. De Gruyter, Berlin, pp. 7-25.

Kumata, T. (1984) Cambium Miners Making Pith Flecks in Broad-leaved Trees. Hoppo Ringyo [Northern Forestry], 36 (5), 6-15. [In Japanese]

Kuznetzov, V.I. (1960) Biology and spatial distribution of Acrocercops amurensis Kuznetsov sp. n. (Lepidoptera, Lithocolletidae)—a serious pest of Mongolian oak. Zoologicheskij Zhurnal, 39 (6), 858-865. [in Russian]

Kuznetzov, V.I. (1975) New species of Microlepidoptera (Lepidoptera, Carposinidae and Gracillariidae) from Tajikistan. Entomologicheskoe Obozrenie, 54 (2), 415-420. [in Russian]

Kuznetzov, V.I. (1979a) New miner-moths (Lepidoptera, Gracillariidae) from the Asiatic part of the USSR. New species of insects from the Asiatic part of the USSR. Trudy Zoologicheskogo Instituta, Akademija Nauk SSSR, 88, 77-84. [in Russian]

Kuznetzov, V.I. (1979b) New subgenera and species of moths (Lepidoptera, Gelechiidae, Gracillariidae) from Siberia and the Far East. New species of insects from Siberia and the Far East. Trudy Zoologicheskogo Instituta, Akademija Nauk SSSR, 81, 87-102. [in Russian]

Kuznetzov, V.I. \& Baryshnikova, S.V. (2000) Two new species of leaf miners from Palaearctic Asia (Lepidoptera: Gracillariidae). Zoosystematica Rossica, 9 (2), 443-444

Kuznetzov, V.I. \& Baryshnikova, S.V. (2001) New and little-known Asian species of the leaf miners (Lepidoptera, Gracillariidae). Trudy Zoologicheskogo Instituta, Akademija Nauk SSSR, 291, 31-46. [in Russian]

Kuznetzov, V.I., Kozlov, M.V. \& Seksyaeva, S.V. (1988) To the systematics and phylogeny of mining moths Gracillariidae, Bucculatricidae and Lyonetiidae (Lepidoptera) with consideration of functional and comparative morphology of male genitalia. Trudy Zoologicheskogo Instituta, Akademija Nauk SSSR, 176, 52-71. [in Russian]

Kuznetzov, V.I. \& Puplesis, R. (1994) Fam. Nepticulidae (Stigmellidae)—pygmy moths. In: Kuznetzov, V.I. (Ed.), Insects and mites - pests of agricultural plants. Lepidoptera. 3 (1). Nauka Publishers, St. Petersburg, pp. 12-23. [in Russian]

Kuznetzov, V.I. \& Stekolnikov, A.A. (1978) The system and evoliution of infraorders in the Lepidoptera (MicropterigomorphaPapilionomorpha) in the light of the functional morphology of genitalia. Entomologicheskoe Obozrenie, 57 (4), 870-890.

Kuznetzov, V.I. \& Stekolnikov, A.A. (2001) New approaches to the system of Lepidoptera of world fauna (on the base of the functional morphology of abdomen). Nauka, St. Petersburg, 462 pp. [in Russian]

Larsen, B., Miller, E.C., Rhodes, M.K. \& Wiens, J.J. (2017) Inordinate fondness multiplied and redistributed: the number of species on Earth and the new pie of life. The Quarterly Review of Biology, 92 (3), 229-265. https://doi.org/10.1086/693564

La Salle, J., Wheeler, Q., Jackway, P., Winterton, S., Hobern, D. \& Lovell, D. (2009) Accelerating taxonomic discovery through automated character extraction. Zootaxa, 2217 (1), 43-55. https://doi.org/10.11646/zootaxa.2217.1.3

Landry, B. (2006) The Gracillariidae (Lepidoptera, Gracillarioidea) of the Galapagos Islands, Ecuador, with notes on some of their relatives. Revue suisse de zoologie, 113 (3), 437-485. https://doi.org/10.5962/bhl.part.80359

Lee, B.-W. \& Byun, B.-K. (2007) Three unrecorded species of family Nepticulidae (Lepidoptera) from South Korea. Journal of Asia-Pacific Entomology, 10 (2), 109-111. https://doi.org/10.1016/S1226-8615(08)60339-8

Li, H. \& Zhang, Z. (2016) Five species of the genus Epicephala Meyrick, 1880 (Lepidoptera: Gracillariidae) from China. Zootaxa, 4084 (3), 391-405. https://doi.org/10.11646/zootaxa.4084.3.5

Li, H., Wang, Z. \& Hu, B. (2015) Four new species of Epicephala Meyrick, 1880 (Lepidoptera, Gracillariidae) associated with two species of Glochidion (Phyllanthaceae) from Hainan Island in China. Zookeys, 508, 53-67. https://doi.org/10.3897/zookeys.508.9479

Liao, C.-Q., Yagi, S., Kobayashi, S. \& Huang, G.-H. (2019) Two new species of Bucculatrix Zeller (Lepidoptera: Bucculatric- 
idae) from China. Zootaxa, 4624 (3), 322-336.

https://doi.org/10.11646/zootaxa.4624.3.2

Linnaeus, C. (1767) s.n. Systema naturae, 1 (2), 533-1327.

Liu, T. \& Wang, H. (2019) Bucculatrix crataega sp. nov. (Lepidoptera: Bucculatricidae), a leaf miner on Crataegus, representing the first formally named species of the family from mainland China. Zootaxa, 4545 (4), 578-584.

https://doi.org/10.11646/zootaxa.4545.4.8

Liu, T., Wang, E., Jiang, Y., Jiang, Z., Jiang, B. \& Teng, K. (2021) First report of the leaf-mining genus Parornix Spuler from China, with descriptions of two new species (Lepidoptera, Gracillariidae, Parornichinae). Zootaxa, 4948 (1), $136-148$. https://doi.org/10.11646/zootaxa.4948.1.8

Liu, Y.Q. \& Yuan, D.C. (1990) A study of the Chinese Caloptilia Hübner, 1825 (Lepidoptera: Gracillariidae: Gracillariinae). Sinozoologia, 7, 181-207.

May, R.M. (2011) Why Worry about How Many Species and Their Loss? PLoS Biol, 9 (8), e1001130. https://doi.org/10.1371/journal.pbio.1001130

Mora, C., Tittensor, D.P., Adl, S., Simpson, A.G.B. \& Worm, B. (2011) How Many Species Are There on Earth and in the Ocean? PLoS Biol, 9 (8), e1001127. https://doi.org/10.1371/journal.pbio.1001127

Newton, P.J. \& Wilkinson, C. (1982) A taxonomic revision of the North American species of Stigmella (Lepidoptera: Nepticulidae). Systematic Entomology, 7 (4), 367-463.

Nielsen, E.S. \& Kristensen, N.P. (1996) The Australian moth family Lophocoronidae and the basal phylogeny of the Lepidoptera-Glossata. Invertebrate Taxonomy, 10, 1199-1302.

Nieukerken, E.J. van (1986a) A provisional phylogenetic check-list of the western Palaearctic Nepticulidae, with data on hostplants (Lepidoptera). Entomologica Scandinavica, 17 (1), 1-27. https://doi.org/10.1163/187631286X00099

Nieukerken, E.J. van (1986b) Systematics and phylogeny of Holarctic genera of Nepticulidae (Lepidoptera, Heteroneura: Monotrysia). Zoologische Verhandelingen, 236 (1), 1-93.

Nieukerken, E.J. van, Doorenweerd, C., Hoare, J.R., Davis, D.R. (2016a) Revised classification and catalogue of global Nepticulidae and Opostegidae (Lepidoptera, Nepticuloidea). ZooKeys, 628, 65-246.

https://doi.org/10.3897/zookeys.628.9799

Nieukerken, E.J. van, Doorenweerd, C., Nishida, K. \& Snyers, C. (2016b) New taxa, including three new genera show uniqueness of Neotropical Nepticulidae (Lepidoptera). ZooKeys, 628, 1-63. https://doi.org/10.3897/zookeys.628.9805

Pereira, H., Belnap, J., Brummitt, N., Collen, N., Ding, H., Gonzales-Espinosa, M., Gregory, R., Honrado, J., Jongman, R.H.G., Julliard, R., McRae, L., Proença, V., Rodrigues, P., Opige, M., Rodríguez, J., Schmeller, D.S., van Swaay, C. \& Vieira, C. (2010) Global Biodiversity Monitoring. Frontiers in Ecology and the Environment, 8 (9), 459-460. https://doi.org/10.1890/10.WB.23

Puplesis, R. (1984a) Contribution to the classification of the Palearctic Nepticulidae (Lepidoptera). Entomological Review, 3 , $149-164$.

Puplesis, R. (1984b) New species of (Lepidoptera) Nepticulidae. Entomological Review, 1, 96-110.

Puplesis, R. (1984c) New species of nepticulids (Lepidoptera, Nepticulidae) from southern Primorye. Entomologicheskoe Obozrenie, 63 (1), 111-125. [in Russian]

Puplesis, R. (1984d) To the classification of nepticulids (Lepidoptera, Nepticulidae) of the Palaearctic fauna. Entomologicheskoe Obozrenie, 63 (3), 582-597. [in Russian]

Puplesis R. (1985) New species of the nepticulid moths (Lepidoptera, Nepticulidae) from southern Far East and Tadzhikistan. Trudy Zoologicheskogo instituta AN SSSR [Proceedings of the Zoological Institute USSR Academy of Sciences], 134, 59-72. [in Russian]

Puplesis, R. (1992) Sistema i evolyutsiya neptikulid (Nepticulidae) s obzorom miniruyushchego obraza zhizni gusenits votryade Lepidoptera. Avtoreferat. Zoologicheskii Institut Rossiiskoi Akademii Nauk, Sankt-Peterburg, 45 pp. [in Russian]

Puplesis, R. (1994) The Nepticulidae of Eastern Europe and Asia: western, central and eastern parts. Backhuys Publishers, Leiden, 291 pp., 840 figs.

Puplesis, R. (2002) Biodiversity: an introduction to global animal and plant diversity. Lutute, Kaunas, 154 pp. [in Lithuanian]

Puplesis, R. \& Diškus, A. (2003) The Nepticuloidea \& Tischerioidea (Lepidoptera) - a global review, with strategic regional revisions. Lutute Publishers, Kaunas, 512 pp.

Puplesis, R. \& Ivinskis, P.P. (1985) Review of nepticulid moth fauna of the Obrussa Braun genus in the USSR and a description of 4 new species_Obrussa capesella sp. n., O. tigrinella sp. n., O. peterseni sp. n., O. sabina sp. n. Lietuvos TSR Mokslu Akademijos darbai (C), 4 (92), 36-46. [in Russian]

Puplesis, R. \& Robinson, G.S. (1999) Revision of the Oriental Opostegidae (Lepidoptera) with general comments on phylogeny within the family. Bulletin of the Natural History Museum, London, Entomology, 68 (1), 1-92.

Puplesis, R. \& Robinson, G.S. (2000) A review of the Central and South American Nepticulidae (Lepidoptera) with special reference to Belize. Bulletin of the Natural History Museum, London, Entomology, 69 (1), 3-114.

Regier, J.C., Mitter, C., Kristensen, N.P., Davis, D.R., Nieukerken, E.J, van, Rota, J., Simonsen, T.J., Mitter, K.T., Kawahara, A.Y., Yen, S.H., Cummings, M.P. \& Zwick, A. (2015) A molecular phylogeny for the oldest (nonditrysian) lineages of 
extant Lepidoptera, with implications for classification, comparative morphology and life history evolution. Systematic Entomology, 40 (4), 671-704.

https://doi.org/10.1111/syen.12129

Regier, J.C., Mitter, C., Zwick, A., Bazinet, A.L., Cummings, M.P., Kawahara, A.Y., Sohn, J.-C., Zwickl, D.J., Cho, S., Davis, D.R., Baixeras, J., Brown, J., Parr, C., Weller, S., Lees, D.C. \& Mitter, K.T. (2013) A large-scale, higher-level, molecular phylogenetic study of the insect order Lepidoptera (Moths and Butterflies). Plos One, 8 (3), e58568. https://doi.org/10.1371/journal.pone.0058568

Remeikis, A., Stonis, J.R., Diškus, A. \& Davis, D.R. (2009) Contribution to the Opostegidae fauna of Central America, with an update cheklist and description of new species from Costa Rica and Mexico (Insecta: Lepidoptera). Acta Zoologica Lituanica, 19 (4), 278-286. https://doi.org/10.2478/v10043-009-0034-3

Rocienè, A. \& Stonis, J.R. (2013) Nepticulidae (Lepidoptera) of East Asia (2). Study of a collection sample deposited at the Russian Academy of Sciences, with descriptions of new species and a checklist. Zootaxa, 3652 (1), 75-116. https://doi.org/10.11646/zootaxa.3652.1

Schmeller, D.S., Böhm, M., Arvanitidis, C., Barber-Meyer, S., Brummitt, N., Chandler, M., Chatzinikolaou, E., Costello, M.J., Ding, H., García-Moreno, J., Gill, M., Haase, P., Jones, M., Juillard, R., Magnusson, W.E., Martin, C.S., McGeoch, M., Mihoub, J.-B., Pettorelli, N., Proença, V., Peng, C., Regan, E., Schmiedel, U., Simaika, J.P., Weatherdon, L., Waterman, C., Xu, H. \& Belnap, J. (2017) Building capacity in biodiversity monitoring at the global scale. Biodiversity and Conservation, $26,2765-2790$. https://doi.org/10.1007/s10531-017-1388-7

Scoble, M.J. (1983) A revised cladistic classification of the Nepticulidae (Lepidoptera) with descriptions of new taxa mainly from South Africa. Transvaal Museum Monograph, 2 (1), 1-105. https://hdl.handle.net/10520/AJA090799001_83

Seksjaeva, S.V. (1989) First data on mining moths of the family Bucculatricidae (Lepidoptera) from southern Primorye with descriptions of 10 new species. Entomologicheskoe Obozrenie, 68 (3), 620-627. [in Russian]

Seksjaeva, S.V. (1992) New species of mining moths of the families Bucculatricidae and Phyllocnistidae (Lepidoptera) from Primorye Territory. Entomologicheskoe Obozrenie, 71 (2), 422-427. [in Russian]

Seksjaeva, S.V. (1996) Additions to the fauna of bucculatricid moths (Lepidoptera, Bucculatricidae) of the Primorsk Territory, Russia. Entomologicheskoe Obozrenie, 75 (4), 884-887. [in Russian]

Shin, Y.-M., Byun, B.-K. \& Lee, B.-W. (2022) First record of the genus Etainia (Lepidoptera: Nepticulidae) with four species new to Korea. Journal of Asia-Pacific Biodiversity. [in press]

Shin, Y.-M., Lim, J., Lee, B.-W. \& Byun, B.-K. (2020) Three Quercus-feeding species of the genus Stigmella Schrank (Lepidoptera: Nepticulidae) new to Korea. Journal of Asia-Pacific Biodiversity, 13 (4), 599-604. https://doi.org/10.1016/j.japb.2020.06.013

Solis, M.A., Davis, D.R. \& Nishida, K. (2005) Biology and systematics of Albusambia elaphoglossumae, a new genus and species of Crambidae (Lepidoptera: Pyraloidea: Crambidae) mining the fronds of Elaphoglossum conspersum (Pteridophyta: Lomariopsidaceae) in Costa Rica. International Journal of Tropical Biology, 53 (3-4), 487-501.

Stonis, J.R., Diškus, A., Carvalho Filho, F. \& Lewis, O.T. (2018a) American Asteraceae-feeding Astrotischeria species with a highly modified, three-lobed valva in the male genitalia (Lepidoptera, Tischeriidae). Zootaxa, 4469 (1), 1-69. https://doi. org/10.11646/zootaxa.4469.1.1

Stonis, J.R., Diškus, A., Fernández-Alonso, J.L., Remeikis, A. \& Solis, M.A. (2021a) New leaf-mining Nepticulidae (Lepidoptera): potential pests of aromatic Lamiaceae plants from equatorial Andes. Zootaxa, 4926 (3), 363-383. https://doi.org/10.11646/zootaxa.4926.3.3

Stonis, J.R., Diškus, A., Katinas, L. \& Solis, M.A. (2018b) Asteraceae: host to the greatest diversity of leafmining Nepticulidae (Lepidoptera) in South America? Proceedings of the Entomological Society of Washington, 120 (4), 856-902. https://doi.org/10.4289/0013-8797.120.4.856

Stonis, J.R., Diškus, A., Monro, A., Dai, X. \& Xu, J. (2021b) Most trumpet moths don’t feed on plants of the nettle family but Paratischeria does: the first discovery of Tischeriidae (Lepidoptera) on Urticaceae in Asia. Zootaxa, 5040 (2), $247-264$. https://doi.org/10.11646/zootaxa.5040.2.5

Stonis, J.R., Diškus, A., Remeikis, A. \& Cumbicus Torres, N. (2016a) First description of leaf-mining Nepticulidae and Tischeriidae (Insecta, Lepidoptera) feeding on the Chilean endemic plant genus Podanthus Lag. (Asteraceae). Zootaxa, 4061 (2), 119-130. https://doi.org/10.11646/zootaxa.4061.2.2

Stonis, J.R., Diškus, A., Remeikis, A., Davis, D.R., Solis, M.A. \& Cumbicus Torres, N. (2016b) The first record of Baccharis L. (Asteraceae) as a host-plant genus for Nepticulidae (Lepidoptera), with description of new Stigmella species from South America. Zootaxa, 4136 (1), 101-128. https://doi.org/10.11646/zootaxa.4136.1.4

Stonis, J.R., Diškus, A., Remeikis, A., Fernández-Alonso, J.L., Baryshnikova, S.V. \& Solis, M.A. (2021c) Documenting trumpet leaf-miner moths (Tischeriidae): new Neotropical Coptotriche and Astrotischeria species, with notes on Sapindaceae as a host-plant family. Zootaxa, 5047 (3), 300-320. https://doi.org/10.11646/zootaxa.5047.3.4.

Stonis, J.R., Diškus, A., Remeikis, A., Gerulaitis, V. \& Karsholt, O. (2016c) Leaf-mining Nepticulidae (Lepidoptera) from 
record high altitudes: documenting an entire new fauna in the Andean páramo and puna. Monograph. Zootaxa, 4181 (1), $1-94$.

https://doi.org/10.11646/zootaxa.4181.1.1

Stonis, J.R., Diškus, A., Remeikis, A., Karsholt, O. \& Cumbicus Torres, N. (2017a) Illustrated review of the leaf-mining Nepticulidae (Lepidoptera) of the central Andes (Peru and Bolivia). Zootaxa, 4257 (1), 1-70.

https://doi.org/10.11646/zootaxa.4257.1.1

Stonis, J.R., Diškus, A., Remeikis, A., Katinas, L., Cumbicus Torres, N., Schuster, J. \& Puplesyte-Chambers, J. (2019a) Diagnostics of new species of Neotropical Tischeriidae (Lepidoptera), with the first record of Coptotriche Walshingham from South America. Zootaxa, 4691 (1), 1-32.

https://doi.org/10.11646/zootaxa.4691.1.1

Stonis, J.R., Diškus, A., Remeikis, A. \& Lewis, O.T. (2020a) Exceptional diversity of Tischeriidae (Lepidoptera) from a single tropical forest site in Belize, Central America. European Journal of Taxonomy, 723, 33-76. https://doi.org/10.5852/ejt.2020.723.1143

Stonis, J.R., Diškus, A., Remeikis, A. \& Nishida, K. (2019b) Discovery of a new species of Ozadelpha van Nieukerken sheds more light on the diagnostics of this controversial genus of Nepticulidae (Lepidoptera). Biologija, 65 (4), $223-235$. https://doi.org/10.6001/biologija.v65i4.4116

Stonis, J.R., Diškus, A., Remeikis, A., Paulavičiūte, B., Katinas, L. \& Cumbicus Torres, N. (2021d) Differentiation of Paratischeria and Neotischeria gen. nov. (Lepidoptera, Tischeriidae), with a description of new, mostly Asteraceae-feeding species from Central and South America. Biologija, 67 (3), 145-173. https://doi.org/10.6001/biologija.v67i3.4511

Stonis, J.R., Diškus, A., Remeikis, A. \& Solis, M.A. (2018c) A Gondwanan concept of Simplimorpha Scoble (sensu lato): a step toward clarity in the generic diagnostics of global Nepticulidae (Lepidoptera). Zootaxa, 4521 (2), 151-182. https://doi.org/10.11646/zootaxa.4521.2.1

Stonis, J.R., Diškus, A., Remeikis, A. \& Solis, M.A. (2018d) The American Brachinepticula gen. nov. and Manoneura Davis (Nepticulidae): a new generic concept based on a reinforced cathrema in the phallus. Biologija, 64 (2), 99-128. https://doi.org/10.6001/biologija.v64i2.3735

Stonis, J.R., Diškus, A., Remeikis, A., Solis, M.A. \& Katinas, L. (2020b) Exotic-looking Neotropical Tischeriidae (Lepidoptera) and their host plants. ZooKeys, 970, 117-158. https://doi.org/10.3897/zookeys.970.54801

Stonis, J.R., Diškus, A., Remeikis, A., Vargas, A.S. \& Solis, M.A. (2020c) Diagnostics and updated catalogue of Acalyptris Meyrick, the second largest genus of Nepticulidae (Lepidoptera) in the Americas. Zootaxa, 4748 (2), 201-247. https://doi.org/10.11646/zootaxa.4748.2.1

Stonis, J.R., Diškus, A., Rocienè, A., Sruoga, V. \& Davis, D.R. (2014) New and little known Coptotriche and Tischeria species (Lepidoptera: Tischeriidae) from Primorskiy Kray, Russian Far East. Zootaxa, 3884 (2), 141-155. https://doi.org/10.11646/zootaxa.3884.2.3

Stonis, J.R., Diškus, A. \& Solis, M.A. (2018e) Two new Fabaceae-feeding Nepticulidae (Lepidoptera) from the Western Hemisphere, including a potential pest of the economically important Centrolobium Mart. ex Benth. Proceedings of the Entomological Society of Washington, 120 (4), 842-855. https://doi.org/10.4289/0013-8797.120.4.842

Stonis, J.R., Diškus, A., Solis, M.A. \& Monro, A.K. (2021e) Diagnostics of Manitischeria gen. nov., an Old-World genus of leaf-mining Tischeriidae, composed of new species and species formerly in Tischeria Zeller. Zootaxa, 4964 (2), $251-287$. https://www.mapress.com/j/zt/article/view/zootaxa.4942.2.8

Stonis, J.R., Remeikis, A., Diškus, A., Baryshnikova, S. \& Solis, M.A. (2021f) What are the smallest moths (Lepidoptera) in the world? Zootaxa, 4942 (2), 269-289.

https://doi.org/10.11646/zootaxa.4942.2.8

Stonis, J.R., Remeikis, A., Diškus, A., Davis, D.R. \& Solis, M.A. (2020d) American Tischeriidae (Lepidoptera) from the collection of the National Museum of Natural History, Washington D.C. Proceedings of the Entomological Society of Washington, 122 (2), 482-505. https://doi.org/10.4289/0013-8797.122.2.482

Stonis, J.R., Remeikis, A., Diškus, A. \& Megoran, N. (2017b) New species of leaf-mining Nepticulidae (Lepidoptera) from the Neotropical and Ando-Patagonian regions, with new data on host-plants. Zootaxa, 4272 (1), 1-39. https://doi.org/10.11646/zootaxa.4272.1.1

Stonis, J.R., Remeikis, A., Diškus, A., Orlovskyte, S., Vargas, S.A. \& Solis, M.A. (2019c) A new leafmining pest of guava: Hesperolyra guajavifoliae sp. nov., with comments on the diagnostics of the endemic Neotropical genus Hesperolyra van Nieukerken (Lepidoptera, Nepticulidae). ZooKeys, 900, 87-110. https://doi.org/10.3897/zookeys.900.46332

Stonis, J.R., Remeikis, A., Diškus, A. \& Solis, M.A. (2017c) The American species of the genus Glaucolepis Braun, 1917 (Neotrifurcula van Nieukerken, syn. nov.) (Lepidoptera: Nepticulidae). Zootaxa, 4338 (3), 489-506. https://doi.org/10.11646/zootaxa.4338.3.5

Stonis, J.R., Remeikis, A., Diškus, A., Vargas, S.A. \& Solis, M.A. (2020e) Opostegidae (Lepidoptera) of the Americas: updated catalog, diagnostics, and new species descriptions. Proceedings of the Entomological Society of Washington, 122 (4), 
929-972.

https://doi.org/10.4289/0013-8797.122.4.929

Stonis, J.R., Remeikis, A., Solis, M.A. \& Karsholt, O. (2021g) Diagnostics and updated checklist of Oriental Pseudopostega (Opostegidae), including the matrona species group with a new, extralimital species discovered in the Mediterranean. Zootaxa, 4933 (3), 341-360.

https://doi.org/10.11646/zootaxa.4933.3.3

Stonis, J.R. \& Rocienè, A. (2013) Nepticulidae (Lepidoptera) of East Asia (1). Re-examination of the male genitalia of types deposited at the Russian Academy of Sciences. Zootaxa, 3652 (1), 1-59. https://doi.org/10.11646/zootaxa.3652.1.1

Stonis, J.R. \& Solis, M.A. (2020) Dishkeya gen. nov., a New World endemic genus of leaf-mining Tischeriidae (Lepidoptera), transferred from Tischeria Zeller. Biologija, 66 (3), 123-135. https://doi.org/10.6001/biologija.v66i3.4307

Swezey, O.H. (1921) Opostega in the Hawaiian Islands (Lep.). Proceedings of the Hawaiian Entomological Society, 4 (3), 531-536.

Vane-Wright, R.I. (1992) Systematics and global biodiversity strategy. Antenna, 16, 49-56.

Vane-Wright, R.I. (1996) Systematics and the Conservation of Biological Diversity. Annals of the Missouri Botanical Garden, $83(1), 47-57$. https://doi.org/10.2307/2399967

Vargas, H.A. \& Moreira, G.R.P. (2012). A New Species of Bucculatrix Zeller (Lepidoptera: Bucculatricidae) associated with Baccharis salicifolia (Asteraceae) in northern Chile. Zootaxa, 3300 (1), 20-33. https://doi.org/10.11646/Zootaxa.3300.1.2

Vermeulen, S. \& Koziell, I. (2002) Integrating global and local values: a review of biodiversity assessment. International Institute for Environment and Development, London, $104 \mathrm{pp}$.

Wang, E., Li, W. \& Liu, T. (2020) Bucculatricidae associated with Asteraceae in China, with one new species (Lepidoptera: Gracillarioidea). Zootaxa, 4766 (1), 181-191. https://doi.org/10.11646/zootaxa.4766.1.10

Wheeler, Q., Bourgoin, T., Coddington, J., Gostony, T., Hamilton, A., Larimer, R., Polaszek, A., Schauff, M. \& Solis, M.A. (2012a) Nomenclatural benchmarking: the role of digital typification and telemicroscopy. ZooKeys, 209, $193-202$. https://doi.org/10.3897/zookeys.209.3486

Wheeler, Q.D., Knapp, S., Stevenson, D.W., Stevenson, J., Blum, S.D., Boom, B.M., Borisy, G.G., Buizer, J.L., de Carvalho, M.R., Cibrian, A., Donoghue, M.J., Doyle, V., Gerson, E.M., Graham, C.H., Graves, P., Graves, S.J., Guralnick, R.P., Hamilton, A.L., Hanken, J., Law, W., Lipscomb, D.L., Lovejoy, T.E., Miller, H., Miller, J.S., Naeem, S., Novacek, M.J., Page, L.M., Platnick, N.I., Porter-Morgan, H., Raven, P.H., Solis, M.A., Valdecasas, A.G., van der Leeuw, S., Vermeulen, N., Vogel, J., Walls, R.L., Wilson, E.O. \& Woolley, J.B. (2012b) Mapping the biosphere: exploring species to understand the origin, organization, and sustainability of biodiversity. Systematics \& Biodiversity, 10 (1), 1-20. https://doi.org/10.1080/14772000.2012.665095

Wilkinson, C. (1981) A supplement to the genus Ectoedemia Busck (Nepticulidae: Lepidoptera) in North America, dealing with some difficult species and also some new ones. Tijdschrift voor Entomologie, 124 (3), 93-110.

Xu, J., Dai, X., Liao, C., Diškus, A. \& Stonis, J.R. (2018) Discovery of Ulmaceae-feeding Tischeriidae (Lepidoptera, Tischerioidea), Tischeria ulmella sp. nov., and the first report of the Quercus-feeding T. naraensis Sato in China. Zootaxa, 4399 (3), 361-370. https://doi.org/10.11646/zootaxa.4399.3.6

Xu, J., Dai, X., Liu, P., Bai, H., Diškus, A. \& Stonis, J.R. (2017) First report on Paratischeria from Asia (Lepidoptera: Tischeriidae). Zootaxa, 4350 (2), 331-344. https://doi.org/10.11646/zootaxa.4350.2.8

Xu, J., Dai, X., Rimšaite, J., Diškus, A. \& Stonis, J.R. (2021) Discovery of the new Coptotriche species in China revealed two novel host-plant families and host-plant orders for Tischeriidae, a family of stenophagous, leafmining lepidopterans. Zootaxa, 5071 (1), 76-96. https://doi.org/10.11646/zootaxa.5071.1.4

Zhang, J., Hu, B., Wang, S. \& Li, H. (2012) Six new species of Epicephala Meyrick, 1880 (Lepidoptera: Gracillariidae) associated with Phyllanthaceae plants. Zootaxa, 3275 (1), 43-54. https://doi.org/10.11646/zootaxa.3275.1.4

Zhang, Z.-Q. (2008) Accelerating biodiversity descriptions and transforming taxonomic publishing: The first decade of Zootaxa. Zootaxa, $2896(1), 1-7$. https://doi.org/10.11646/zootaxa.2896.1.1

Zhang, Z.-Q. (2011) Describing unexplored biodiversity: Zootaxa in the International Year of Biodiversity. Zootaxa, 2768 (1), $1-4$. https://doi.org/10.11646/zootaxa.2768.1.1 